\title{
Bioactive Nutrients and Nutrigenomics in Age-Related Diseases
}

\author{
Tania Rescigno ${ }^{1}$, Luigina Micolucci ${ }^{2,3}$, Mario F. Tecce ${ }^{1}$ and Anna Capasso ${ }^{1, *}$ \\ 1 Department of Pharmacy, University of Salerno, Fisciano 84084, Italy; \\ trescigno@unisa.it (T.R.); tecce@unisa.it (M.F.T.) \\ 2 Computational Pathology Unit, Department of Clinical and Molecular Sciences, \\ Università Politecnica delle Marche, Ancona 60120, Italy; 1.micolucci@univpm.it \\ 3 Laboratory of Experimental Pathology, Department of Clinical and Molecular Sciences, \\ Università Politecnica delle Marche, Ancona 60120, Italy \\ * Correspondence: annacap@unisa.it; Tel.: +39-089-989744
}

Academic Editor: Philippe Bulet

Received: 18 November 2016; Accepted: 3 January 2017; Published: 8 January 2017

\begin{abstract}
The increased life expectancy and the expansion of the elderly population are stimulating research into aging. Aging may be viewed as a multifactorial process that results from the interaction of genetic and environmental factors, which include lifestyle. Human molecular processes are influenced by physiological pathways as well as exogenous factors, which include the diet. Dietary components have substantive effects on metabolic health; for instance, bioactive molecules capable of selectively modulating specific metabolic pathways affect the development/progression of cardiovascular and neoplastic disease. As bioactive nutrients are increasingly identified, their clinical and molecular chemopreventive effects are being characterized and systematic analyses encompassing the "omics" technologies (transcriptomics, proteomics and metabolomics) are being conducted to explore their action. The evolving field of molecular pathological epidemiology has unique strength to investigate the effects of dietary and lifestyle exposure on clinical outcomes. The mounting body of knowledge regarding diet-related health status and disease risk is expected to lead in the near future to the development of improved diagnostic procedures and therapeutic strategies targeting processes relevant to nutrition. The state of the art of aging and nutrigenomics research and the molecular mechanisms underlying the beneficial effects of bioactive nutrients on the main aging-related disorders are reviewed herein.
\end{abstract}

Keywords: aging; bioactive nutrients; dietary; nutrigenomics; oxi-inflamm-aging; molecular pathological epidemiology

\section{Introduction}

Aging can be viewed as a multifactorial process stemming from the interaction of genetic and environmental factors, which include lifestyle. It is characterized by the onset of several age-related diseases (ARDs) such as dementia, osteoporosis, arthritis, diabetes, cardiovascular diseases (CVDs), neurodegenerative disorders, and cancer which, though not unique to old age, are nonetheless closely related to it. The physiological decline experienced by organisms over time is a key factor in increasing the risk of developing ARDs [1,2]. As human life expectancy expands, the number of patients with ARDs is rapidly increasing and will continue to mount, posing a serious challenge to healthcare systems globally [3]. ARDs are also becoming a key social and economic problem [4]. Progress in the understanding of genetic associations, particularly via genome wide association studies, has disclosed a substantial contribution of genes to human aging and ARDs [4]. 
Ample evidence from several species indicates that the maximum age attainable is genetically determined and that multiple mitochondrial DNA polymorphisms are associated with longevity [5]. The several theories of aging that have been devised over the past few decades have failed to provide an answer to the questions: "why do we age?", "what can we do to live longer?". However, the notion of aging as a complex multifactorial process has superseded previous constructs based on single factors [6]. In fact, whereas some of the processes that characterize physiological aging can be explained by individual factors, no single theory can account for aging as a process. Several different molecular mechanisms linking aging and ARDs have been advanced [3].

Various lines of research have demonstrated that telomerase activity and telomere length shortening play important roles in aging, Alzheimer's disease (AD) and type 2 diabetes (T2DM) $[7,8]$; a reduced capacity for DNA repair and genomic instability are commonly seen in both aging and cancer $[4,9,10]$; mitochondrial dysfunction is a hallmark of aging and ARDs, including CVDs and cancer [11,12]; and metabolic syndrome, diabetes, CVD, neurodegenerative diseases, and other ARDs are associated with chronic inflammation [13-15].

In fact, most of the phenotypic characteristics of aging are the result of an age-related, low-grade, chronic proinflammatory status that has been designated "inflammaging" [16], which is partly under genetic control. Moreover, up-regulation of inflammatory responses induces senescence, and inflammatory changes are shared by several age-related diseases. Oxidation-inflammation has thus been hypothesized to be the main cause of aging (oxi-inflamm-aging) [17]. The aging-related chronic oxidative stress affects all cells, especially those of regulatory systems (nervous, endocrine and immune systems) and the communication among them, adversely affecting homeostasis and the maintenance of the health status. Since the redox state and functional capacity of immune cells are related to longevity, the immune system is also likely to be critically involved in aging and to affect its rate. Moreover, the role of the immune system in senescence is likely to be pervasive, as also confirmed by the demonstration that adequate dietary antioxidants improve immune function, reduce oxidative stress, and increase longevity [18].

Human molecular processes are influenced by physiological pathways as well as exogenous factors, including dietary components. Since nutrients directly affect physiological changes, the diet has substantive effects. For instance, bioactive molecules capable of selective modulation of specific metabolic pathways affect the development/progression of cardiovascular and neoplastic disease. As bioactive nutrients are increasingly identified, their clinical and molecular chemopreventive effects are characterized and systematic analyses encompassing all "omics" technologies (transcriptomics, proteomics and metabolomics) are conducted to investigate their effects. Nutrigenomic knowledge regarding physiological status and disease risk is expected to lead to the development of improved diagnostic procedures and of therapeutic strategies targeting processes related to nutrition.

The state of the art of aging and nutrigenomics research and the molecular mechanisms underlying the beneficial effects exerted by bioactive nutrients on the main ARDs are reviewed herein.

\section{Aging and Age-Related Diseases}

\subsection{Aging Theories}

A number of theories have been proposed to account for the unavoidable effects of aging. The main aging theories are the genetic theory, cellular aging theory, the neuroendocrine theory, the immunological theory, the free-radical theory, and the network theory.

The genetic theory [2] suggests that aging is the direct consequence of a genetic programme, and that the lifespan of each animal species is regulated by genetic factors. Indeed, in the human species the members of some families are particularly long-lived and diseases such as Down, Werner, and Hutchinson-Gilford syndrome, which are characterized by an accelerated aging process and a shortened lifespan, are hereditary $[19,20]$. Some studies do not focus on "gerontogenes", i.e., genes that actively determine aging, but rather on "longevity assurance genes", genes that guarantee a long 
life. Extreme longevity appears to be related to a complex genetic pattern rather than to a few isolated genes $[19,20]$.

According to the cellular theory, cellular senescence limits the number of divisions that normal human cells can undergo in culture [21]. Renowned experiments conducted by Hayflick have demonstrated that embryo fibroblasts from a variety of animal species can replicate only a finite number of times in proportion to the lifespan of the individuals of the species [21]. The Hayflick limit is reached after a given number of cell divisions [22-25] or due to a reaction to given molecular events. Replicative senescence, which correlates to the number of cell divisions determined by telomere length, can therefore be considered as one of the causes of aging, whereas stress-induced senescence is a response to a sudden modification of the genome and to DNA damage. Cellular senescence should therefore be viewed as a response to age-related changes, which accelerate the organism's aging process. This view of senescence is consistent with the theories of damage build-up (like the free-radical theory), which may explain the ultimate cause of cell senescence through aging [26].

The hypothesis underpinning the neuroendocrine theory of aging is that aging results from the dysregulation of the neuroendocrine system by chronic exposure to physical, biological, or emotional stress, which may overburden or damage the organism's adaptive capacity, leading to "adaptation diseases" and ultimately death [27-31]. The integration of such stimuli seems to be performed by the hypothalamus through information provided by a variety of brain structures, chiefly the cerebral cortex, the limbic lobe, and the reticular formation. The hypothalamic signals induce production and secretion of pituitary hormones, which regulate key body functions, and stimulate peripheral endocrine glands (e.g., adrenal glands, thyroid, and gonads), whose hormone products are conveyed to their remote targets through the circulation [26]. In this highly sensitive, closed-circuit system, hormone production is modulated to meet the changing needs of the body; these are induced by continuously changing stimuli, which are stressful in the largest sense of the word, encompassing for instance heat-cold, food-fast, activity-rest, and sleep-vigil. Over time, the mechanism may undergo functional alterations and bring about irreversible modifications in all organs and apparatuses [32-42].

The immunological theory of aging holds that physiological aging is related to immune system dysregulation [43]. The term "immunosenescence" has been proposed to describe the aging-related impairment of immunocompetence, which makes the elderly more susceptible to disease and increases morbidity and mortality from diseases linked to infectious agents via impairment of the response to acute infection as well as vaccines. According to some researchers, immunosenescence also involves an increased susceptibility to cancer and a diminished capacity of self-recognition, which lead to autoimmune disorders [44].

The best known age-related changes affecting the immune system include: (i) thymus involution, resulting in decreased production of $\mathrm{T}$ cells, which are responsible for acquired and cell-mediated immunity [45]; (ii) lymphocyte remodelling, which is closely related to the T-cell compartment [46-58]; and (iii) changes in the secretion pattern of pro- and anti-inflammatory cytokines [16,59-69].

The free radical theory rests on the evidence that aerobes produce oxygen-centred free radicals which irreversibly damage biological structures. Free radicals are formed inside cells as a result of the participation of oxygen in energy. Mitochondrial respiration generates reactive oxygen species (ROS) through leakage of intermediates from the electron transport chain [70]. ROS are highly unstable molecules, due to an unpaired electron, and strive to attain a stable state by appropriating electrons from nearby molecules, which in turn become unstable, thus propagating the instability.

The network theory, formulated in 1989 by Franceschi and colleagues [71], unifies a number of previous theories [72]. This constructs accepts that aging depends on genetic and environmental factors. The organism is exposed to endogenous and exogenous noxious agents that are physical (radiation, heat), chemical (toxic metabolites, free radicals), and biological (viruses and pathogenic microorganisms). The main mechanisms activated by the organism to preserve homeostasis include DNA repair, stimulation of the antioxidant system, production of anti-inflammatory cytokines and heat shock proteins, activation of poly-ADP-ribose polymerase (a DNA-repairing nuclear enzyme), 
and apoptosis, which is considered as the ancestral process by which damaged, mutated, infected, or transformed cells are removed [54,56]. All these cellular and molecular processes have become layered throughout evolution [56].

\subsection{Inflammaging}

The term inflammaging, introduced by Franceschi [16], indicates that aging is characterized by a low-level, chronic, asymptomatic, systemic inflammatory state involving the body's adaptive systems in a sustained effort to provide a myriad, low-grade inflammatory responses that tend to become chronic and are frequently asymptomatic [54,73-78]. It has been shown that this type of chronic cell stress can induce the acquisition of the senescence-associated secretory phenotype (SASP), which is characterized by the activation of a proinflammatory transcriptional programme $[79,80]$. Patients report vague and non-specific signs and systemic symptoms that are difficult to organize into a diagnosis. Inflammaging is thus the result of the body's ability to adapt and react to the effects of a variety of stress factors that induce the accumulation of molecular and cellular damage.

\section{Physiopathogenesis}

The relationship between chronic systemic inflammation and aging is widely accepted. Strong evidence indicates that most of the phenotypic characteristics of the aging process are induced by inflammaging, which is partly under genetic control and which results from continuous antigenic stimulation that continues after reproductive age, a phenomenon for which evolution has not provided [67,81,82]. The consequent cellular damage appears to increase the risk of death among the elderly and to affect longevity adversely [83]. A number of genetic, cellular, and serological markers of inflammaging have been identified, such as an immunophenotype characterized by a reduction in naive $\mathrm{T}$ cells and an accumulation of memory cells, increased levels of proinflammatory cytokines, and significant alterations in the frequency of functional pro- or anti-inflammatory polymorphisms $[69,73,84]$. Inflammaging is characterized by macrophage activation and by expansion of specific T-cell clones (megaclones) directed to common virus antigens such as cytomegalovirus (CMV) and Epstein-Barr virus [85-90]. In a study of 121 individuals aged 25 to 100 years, $18 \mathrm{CMV}$-negative (-) and 103 CMV-positive (+), CMV+ subjects exhibited an accelerated age-related reduction of naive CD8+ $\mathrm{T}$ cells as well as a progressive increase in CD28- and CD8+ effector T cells [90]. Therefore, CMV seropositivity seems to be associated with multiple phenotypic and functional alterations of T-cell immunity that are considered as biomarkers of aging [90]. Herpes simplex virus (HSV) infection is another chronic infection that may affect the immune/inflammatory response in the elderly and that appears to be a cofactor in the damage produced by AD [91-93].

The complex inflammatory status that is the hallmark of inflammaging is mainly related to the increase in circulating proinflammatory cytokines. Cytokines are a class of soluble proteins that are responsible for the communication among the different immune system components. They play an important role in inflammation by acting on the targeting, regulation, and termination of inflammatory processes, and also participate in the aging process. Aging involves a reversible decrease in interleukin (IL)-2, a cytokine that has a role in the development of Th1 populations and in increased production of proinflammatory mediators such as IL-1, IL-6, and tumour necrosis factor (TNF) $\alpha$ [56]. The increase in circulating age-related inflammatory markers could underpin the reduced ability of elderly organisms to cope with various stressors. Inflammaging may also generate ROS that cause oxidative damage and induce an increase in cytokine release, fuelling a vicious circle where tissue damage and repair mechanisms are simultaneously activated, giving rise to a chronic proinflammatory state. The damage accumulates slowly and asymptomatically over decades, resulting in aging and ARD development [54,74-78]. ROS are also capable of exerting strong effects on gene expression and are implicated in the pathogenesis of numerous ARDs such as atherosclerosis, T2DM, neurodegenerative disorders, osteoporosis, and osteoarthritis, which all share a strong inflammatory/immunological component. Moreover, oxidative stress and ROS induce apoptosis and may act as mediators, 
influencing other transcription factors, like NF- $\mathrm{B}$ and AP-1 [73]. Aging-related alterations in apoptosis may thus account for some prominent features of immunosenescence [82], such as the accumulation of memory cells, megaclone expansion, the reduced T-lymphocyte repertoire, and the increased incidence of autoimmune disorders.

Moreover, emerging evidence suggests that DNA damage response (DDR) signalling is a key mechanism linking the build-up of DNA damage, cell senescence, and organism aging [94]. This evidence suggests the involvement of epigenetic modifications; for instance microRNAs, small, non-coding RNAs involved in post-transcriptional regulation, have been hypothesized to play a key role in the diffusion of DDR/SASP signalling to non-damaged surrounding cells during aging, suggesting that the identification of new DDR/SASP signalling components may enable the development of novel therapeutic interventions against ARDs [9]. The hypothesis has also been advanced that microRNAs may be harnessed as innovative tools to detect and target senescent cells and to develop therapeutic interventions that can slow down the proinflammatory programme activated in senescent endothelial cells [95].

Conversely, the cellular and molecular mechanisms related to the body's ability to respond to chronic oxidative stress and inflammation appear to play an important role in promoting longevity and in avoiding/delaying the major ARDs. A role for inflammatory cells and molecules in the pathogenesis of ARDs such as atherosclerosis, AD, and Parkinson's disease has clearly been documented. The control of inflammation may be capable of fostering successful aging. That this goal can be achieved is demonstrated by centenarians, living examples of successful aging who have attained the desirable form of aging, because they do not suffer from chronic debilitating diseases, they are physically self-sufficient, and have preserved their cognitive abilities. The study of centenarians has the potential to provide insight into the biological basis of healthy aging or on the combination of genes and lifestyle that can prevent the major ARDs. The INCHIANTI study, which ended in 2004 [96], showed that healthy elderly subjects have high levels of IL-6, IL-1 and C-reactive protein (CRP) compared with healthy young subjects. A further study of a group of Italian centenarians has shown that individuals genetically predisposed to produce IL-6 in old age are less likely to reach the extreme boundaries of human lifespan.

Lio and colleagues [76] have assessed the levels of two cytokines, the anti-inflammatory IL-10 and the proinflammatory TNF $\alpha$, in a group of centenarians and found that compared with younger subjects they express genes coding for high levels of IL-10 and low levels of TNF $\alpha$. Moreover, the frequency of the variants (polymorphisms) of key genes involved in immune response and low-grade inflammation are found with different frequencies in centenarians and young individuals [89,97,98]. The identification of an anti-inflammatory genotype in centenarians suggests that chronic inflammation is a key predictive marker of mortality/morbidity.

Evidence of inflammaging has also been found in healthy centenarians, who exhibited up-regulation of markers such as the anti-inflammatoryIL-10 and the proinflammatory TGF $\beta[99,100]$; these data suggest that anti-inflammaging activity is also present in these subjects, and is equally important for longevity, and that longevity is the result of the balancing of such conflicting processes [101]. A lifespan exceeding 90 years seems to have a strong genetic basis, explaining why the almost-100-year olds and centenarians tend to belong to the same families. Longevity seems to be influenced by a complex genetic pattern, not by a few isolated genes, suggesting selection for genes and genetic variants associated with strong immune responses and inflammation.

The hypothesis has been advanced [88,102] that an effective inflammatory response directed at combating infection at a young age may eventually be the cause of conditions such as arthritis, diabetes, CVD, and neurodegenerative disorders in old age. The dual biological role of inflammation, positive at a young age and negative in old age, is consistent with antagonistic pleiotropy theory, whereby a gene can exert opposite effects in different periods of life. Inflammation is not a negative phenomenon per se; indeed, in responding to various stimuli, the immune system enacts a complex series of local and systemic reactions that limit tissue damage, isolate and destroy infectious agents, and activate 
repair processes. Its adverse effects are related to the increased life expectancy, which has not been provided for by evolution. An extended lifespan involves that the immune system continues to react against external agents for decades longer than it has been programmed for, and that such increased antigenic load eventually establishes a chronic inflammation that contributes to the deterioration of various organs, becoming a risk factor for all ARDs. Elderly individuals with higher blood levels of an acute-phase protein, CRP, are especially prone to chronic inflammatory diseases.

The systemic consequences of inflammaging are associated with a pattern of changes that has been designated "frailty" [101]. Epidemiological studies suggest that such changes promote an atherogenic profile that is shared by other chronic inflammatory ARDs. Other genetic and environmental factors that promote disease continue to exert their effects and even determine the main organ that will be affected. Differences in inflammatory status partly explain why not all elderly subjects who share the same risk factors go on to develop ARDs. The genetically determined immune system potential is therefore gradually depleted over time. Improvements in hygienic conditions may have reduced significantly the antigenic overload, delaying the depletion. This factor, besides the reduced mortality from acute infectious diseases, may contribute to the increased life expectancy and to the increase in the number of subjects who reach the extreme boundaries of the human lifespan.

\subsection{Aging-Related Disorders}

Inflammation is a chronic, systemic cause of several ARDs, including atherosclerosis, CVD, AD and cancer. Recent data show that chronic systemic inflammation contributes to anxiety, depression, cognitive decline, insulin resistance and adult-onset diabetes, obesity, and Parkinson's disease.

\subsubsection{Cancer}

Cancer mostly affects elderly subjects. In industrialized countries, average age at cancer diagnosis is close to 70 years, and is expected to increase [103]. Prolonged exposure to carcinogenic factors, increased cell susceptibility to environmental carcinogens [104,105], and immunosenescence [106] are believed to be major reasons for the predominance of cancer in the later decades of life. A strong link between the chronic inflammation induced by chemical, biological, mechanical, or physical lesions and cancer is well documented. For example, bowel inflammatory disease, ulcerative colitis, and Crohn's disease predispose to the development of cancer of the large intestine or terminal ileum $[107,108]$ and Helicobacter pylori infection is associated with atrophic gastritis, mucosal dysplasia, and gastric adenocarcinoma. Inflammation is also involved in the development of solid tumours such as colon cancer, as demonstrated by a prospective case-control study where the 172 subjects (out of 22,887 adults who were followed for 11 years) who developed colon cancer had higher plasma CRP [109]. Cancer susceptibility and severity may be associated with functional polymorphisms of cytokine genes involved in regulating inflammation; in particular, polymorphisms of IL-6 and IL-10 genes may influence cancer susceptibility and in some cases its prognosis.

A variety of different mechanisms may link inflammation to cancer, since (i) induction of angiogenesis by inflammatory factors promotes cancer progression [110]; (ii) increased release of proinflammatory factors and certain cytokines such as IL-1, TNF $\alpha$ and interferon are involved in inflammation and cancer development [110,111]; (iii) free-radical production promotes carcinogenesis [110].

The inflammatory state is a key factor in the intermediate stages of tumour development. In cancer, genetic damage triggers disease onset and inflammation fuels the process. In 1978, Alberto Mantovani found that innate immunity cells tend to cluster around some tumours [112]. Pollard and colleagues subsequently showed that cancer cells "re-educate" macrophages, turning them into cytokine and growth factor factories that stimulate cancer growth by acting as tumour promoters [112]. Macrophages produce TNF, which activates nuclear factor NF- $\mathrm{kB}$ in cancer cells, triggering the production of proteins that stop apoptosis and activate cell proliferation. The innate immune system is thus harnessed to help the tumour grow. How the process starts is, however, still unclear [112]. 
Interestingly, cancer development is largely avoided or delayed in centenarians, where changes in some specific microRNAs have been detected in plasma and leukocytes [113].

\subsubsection{Atherosclerosis}

Almost $50 \%$ of all deaths in the developed world and $25 \%$ of those occurring in developing countries are related to CVD. Atherosclerosis is the leading cause of heart disease and stroke. Atherosclerosis, which used to be considered as a disease of lipid accumulation, is now viewed as a chronic inflammatory disorder affecting large and medium-sized vessels [114]. Lesions arise in childhood as reversible lipid streaks which in old age tend to become plaques that may reduce the arterial lumen, or else become ulcerated and give rise to thrombosis that may result in lumen occlusion. Clinical manifestations range from angina pectoris and myocardial infarction when the coronary arteries are involved, stroke if it is the arteries of the central nervous system and peripheral arterial disease if it is the peripheral circulation. Vessel branches and bends are more prone to host atherosclerotic lesions, due to surface friction (hemodynamic stress), an important factor in intima thickening. Early atherosclerotic lesions are identified by the dysfunction induced by cardiovascular risk factors (smoking, hypercholesterolaemia, hyperhomocysteinaemia, hypertension, obesity and diabetes mellitus, and possibly infectious and immunological causes) and by the accumulation and subsequent oxidation of low-density lipoprotein (LDL). Endothelial dysfunction evolves to a situation characterized by monocyte and T-cell migration and adhesion to the intima in response to the surface expression of endothelial adhesion molecules, e.g., selectins, VCAM-1, ICAM-1 and chemotactic signals (e.g., MCP-1). The monocytes recruited to the intima proliferate and differentiate into macrophages that phagocytose oxidized lipoproteins, turning them into foam cells that characterize fatty streaks. Secretion of cytokines and growth factors, mainly from macrophages, induces migration of smooth muscle cells from the media to the intima and their proliferation and differentiation into a phenotype that synthesizes extracellular matrix. As a result, lipid streaks are transformed into advanced lesions, i.e., fibrous plaques formed by a fibrous cap that encloses a lipid core. LDL accumulation is due not only to the increased permeability of the functionally damaged endothelium, but also to its ability to bind the extracellular matrix constituents in the intima. LDLs undergo oxidation and are then trapped in the extracellular matrix of the subendothelial space where they play a key role in the development of the chronic intimal inflammation. LDLs are oxidized by enzymes and oxidative metabolites produced by arterial wall cells, especially monocytes-macrophages recruited in the intima. In this context, they activate some transcription factors (e.g., NF- $\mathrm{kB}$ ) in cells (endothelium, macrophages, smooth muscle cells), which induce the expression of genes encoding adhesion molecules, cytokines, and growth factors and trigger the inflammatory response, activate platelets and cause aggregation. Fibrous plaques that develop ulceration, bleeding, thrombosis, and calcification, lead to the third and most severe atherosclerotic stage: complicated lesions. Plaque fissuring is held to be the result of several factors, particularly plaque inflammation and an abundant lipid component, which would make the plaque less resistant to the blood component. Inflammatory cells and especially macrophages produce hydrolytic enzymes such as metalloproteases that can lyse the collagen of the fibrous cap, impairing its resistance to hemodynamic stress.

\subsubsection{Alzheimer's Disease}

$\mathrm{AD}$ is the most common neurodegenerative disease in the West. The aging of the population is making it an increasingly severe public health problem. The disease manifests with a progressive decline in memory and intellectual abilities, impoverishment of language and behavioural skills, and disorientation. Characteristic neuropathological features are senile plaques (SPs), neurofibrillary tangles (NFTs) and amyloid angiopathy. NFTs are accumulations of dystrophic neurites containing double helix filaments whose main component is the phosphorylated form of $\tau$ protein encoded by chromosome 17 and associated with microtubules. $\beta$ amyloid deposits are seen both in brain vessel walls and, more typically, in SPs, which consist of a central core of $\beta$ amyloid fibrils surrounded by 
a ring of dystrophic neurites, reactive astrocytes and microglia. The $\beta$ amyloid protein originates from the cleavage of a precursor consisting of two fragments of 40 (A $\beta 1-40)$ and 42 amino acids (A $\beta 1-42)$. In the familial form of $\mathrm{AD}$, more than $50 \%$ of patients bear mutations in the amyloid precursor protein on chromosome 21 [115], presenilin 1 gene on chromosome 14 [116], and presenilin 2 gene on chromosome 1 [117]. These changes are associated with increased production of $A \beta 1-42$, which is highly toxic for neurons and is the main SP component. However, the role of genetic factors in the pathogenesis of sporadic AD is not completely clear, and multiple risk factors are likely to be involved.

Immune responsiveness in AD appears to be altered [118,119]. Some acute-phase proteins and elements of the immune system have been detected in the brain of these patients besides the classic signs of inflammation such as oedema and neutrophil invasion. Alterations found in the brains of AD patients but not in age-matched healthy controls include a greater number of receptors for immunoglobulin and for the complement, increased microglial expression of the major histocompatibility complex, increased production of cytokines (IL-1 $\beta$, IL-6), increased acute-phase proteins (plasma $\alpha$ 1-antichymotrypsin, $\alpha 1 \mathrm{AC})$ and infiltration of T lymphocytes in tissues [120-123]. A case-control study [120] showed that plasma $\alpha 1 \mathrm{AC}$ levels are related to the degree of cognitive impairment in AD patients and that peripheral markers of inflammation or altered immune response could be used to monitor disease progression. The role of inflammation is further stressed by epidemiological studies showing that the long-term use of non-steroidal anti-inflammatories may protect against AD [124]. Several studies have reported increased concentrations of some cytokines and their receptors, which regulate and amplify immune responses, whereas lymphocytic infiltration does not seem to play a large role. The complement system is involved in these reactive processes [125]. Its activation prepares the cell for phagocytosis and stimulates cytolysis. Antibodies against complement components have been described in brain tissue of AD patients, but they showed no binding in tissue from age-matched controls. These and other data indicate that AD involves activation of the complement cascade to produce a lytic membrane complex; neurons exposed to the complex are protected by an increased synthesis of inhibitors. However, self-destruction and phagocytosis are the predominant processes. These findings provide valuable information for AD treatment and raise questions on issues such as the relationship between $\beta$ amyloid and inflammatory response. $\beta$ amyloid appears to directly activate components of the inflammatory response such as the complement cascade and microglia [126] and macrophage activity.

In conclusion, the brain lesions associated with AD, such as NFTs and SPs, are characterized by a broad spectrum of inflammatory mediators produced by cells residing in the brain, including neurons. Though of secondary importance compared with the fundamental cause that determines their formation, there is strong evidence that inflammation exacerbates neuronal loss. Consequently, the $\mathrm{AD}$ risk is substantially influenced by several polymorphisms in the promoter region of genes, and other non-coding regions, coding for inflammatory mediators. Alleles that support the up-regulation of inflammatory mediators or that favour the down-regulation of anti-inflammatory mediators are more frequent in AD patients than in controls. Since polymorphisms are fairly common in the general population, there is a strong possibility that all individuals inherit one or more high-risk alleles [123,127-134].

\section{Bioactive Nutrients and Nutrigenomics}

The interactions among genomic and environmental factors is crucial in the development/ progression of several human diseases. The diet is a key environmental factor with a prominent role in disease aetiology [135].

The diet primarily meets the metabolic and energy requirements of body composition homeostasis. However, it may also enhance health through regulation of specific processes [136], positively counteract inflammaging and the epigenetic changes associated with aging, and promote health [137,138]. Indeed, nutrients are considered as dietary signals capable of affecting both metabolic programming and cell homeostasis. Bioactive nutrients or chemopreventive molecules exert effects on human 
health and reduce disease risk through specific molecular mechanisms [139-141]; experimental and epidemiological evidence emphasizes the potential of dietary components, both macronutrients (carbohydrates, protein, fat, and fibre) and micronutrients (antioxidant vitamins and minerals) as first-line interventions in the prevention and treatment of cancer and other diseases [140,141]. Nutritional research studies span numerous disciplines and are conducted at the molecular and genetic level [142,143]. For instance, a recent review of studies into the effect of the Mediterranean diet (MD) on inflammaging, cancer, and most ARDs has found that the MD and its individual bioactive nutrients modulate several interconnected processes involved in tumorigenesis, the inflammatory response (e.g., free radical production, NF- $\mathrm{KB}$ activation, and the expression of inflammatory mediators), and the eicosanoid pathway. In particular, the authors highlight the evidence indicating that the MD can affect the balance between pro- and anti-inflammaging and some emerging topics, such as the maintenance of gut microbiota homeostasis and the epigenetic modulation of carcinogenesis through specific microRNAs [144]. Moreover, a parallel randomized trial has investigated the effect of a healthy diet on inflammaging and its consequences on the prevention of age-related decline in European elderly individuals [145].

The effects of food at the genetic and epigenetic level are examined by two new approaches, nutrigenetics and nutrigenomics, which assess the influence of dietary components on health and disease onset, progression, and treatment. Nutrigenetics examines how genetic variation affects the response of an organism to a given diet, evaluating the risks and benefits of specific diets and dietary components and formulating "personalized nutrition" recommendations. Nutrigenomics investigates how nutrients affect gene expression and downstream processes [146].

Nutrigenomics and nutrigenetics clearly straddle multiple research fields that span from nutrition to bioinformatics, molecular biology, genomics, functional genomics, epidemiology, epigenomics, transcriptomics, metabolomics, proteomics, lipidomics, and the microbiome [147].

To an extent, nutrigenomics approaches pharmacogenomics, which involves the systematic study of the effect of drugs on the genome [148]. However, whereas drugs are pure compounds, acting with affinity and selectivity on a limited number of biological targets through administration of precise and low doses, nutrigenomics addresses the complexity and variability of the diet, where some nutrients may be consumed in high albeit non-toxic concentrations (from $\mu \mathrm{mM}$ to $\mathrm{mM}$ ) and may also bind to targets with different affinities and specificities [149,150].

Eating patterns influence gene, protein expression and metabolism and may thus be considered as endogenous cellular mediators. Once it is absorbed at the cell level, a nutrient is capable of interacting through specific signalling pathways, and even small changes in its structure may involve differential activation of metabolic steps. Fatty acids and their degree of carbon chain unsaturation are a valuable example, since $n-3$ polyunsaturated fatty acids promote anti-inflammatory pathways, whereas $n-6$ polyunsaturated fatty acids induce synthesis of proinflammatory molecules; in addition, trans fatty acids increase plasma LDL-cholesterol [151-153] whereas $n-3$ polyunsaturated fatty acids do not have this effect.

It is likely that several dietary compounds exert their protective and restorative action through modulation of distinct signal transduction pathways. Nutrients have been found to affect gene expression as a consequence of a direct interaction with transcription factors [154]; for instance fat-soluble ligands, such as vitamin A/D, activate their cognate nuclear receptors for ligand-dependent transcriptional regulation. Population studies based on dietary questionnaires supply useful data to relate dietary intake to phenotypes and to the risk of developing a number of diseases [155]. Moreover, actual nutritional intake can be monitored by measuring specific molecules in blood, urine, fat, and tissues, an approach that can also enable identification of the nutritional biomarkers that connect nutrition and health. Altered serum lipids (e.g., cholesterol, triglycerides), increased blood pressure, and reduced insulin sensitivity are common predictors of diet-related diseases. A broad biomarker panel, rather than a search limited to single markers, would be able to provide exhaustive information to characterize the health status of individuals. 
The application of "omics" technologies to nutrition and bioinformatic data analysis allows integrating information from the closely interconnected fields of transcriptomics, proteomics, and metabolomics, to identify specific differences related to nutritional habits and to investigate the mechanisms that cause changes [147,148,156-161].

The risk of developing disease is partly under genetic control. Nutrigenetics investigates the genetic variations induced by individual nutrients, for instance by relating single nucleotide polymorphisms and point mutations in DNA sequences to diet responsiveness [162,163]; population differences in single nucleotide polymorphisms can help risk assessment and prediction, enabling formulation of lifestyle recommendations. Phenylketonuria has been the first case of a condition induced by a single gene defect to be successfully treated with a dietary, i.e., nutrigenetic, intervention, namely a low-phenylalanine diet [164].

Nutriproteomics, a recent branch of proteomics, studies protein structure and function and protein-protein interactions to identify the molecular targets of dietary components [165-195]. Here, too, the goal is to detect differences in protein patterns induced by given interventions, for instance a dietary treatment. In turn, proteomics analyzes the effect of dietary components at various levels, investigating peptides as bioactive markers and seeking information on nutritionally relevant biological pathways in view of the development of dietary interventions to be applied in the clinic. Proteomics, also combined with gene expression analysis, has been used in cancer prevention studies to identify novel biomarkers [196-206].

A quantifiable change connecting a normal or pathological condition to modulation of mRNA, a protein, or the concentration of a metabolite can be used as a molecular biomarker. In particular, a protein concentration is a practical biomarker and a valuable diagnostic tool, due to its reproducible and accurate determination [207]. The dietary levels of most nutrients are only weakly biologically active and probably have several targets. When a biomarker is tested, the timing of its response(s) should be considered according to the nutrient's bioavailability and bioefficacy. Notably, although biomarkers may correlate with nutrient intake, their modulation may in fact be the result of a more complex process including intake, absorption, metabolism, and excretion, as well as environmental factors and genetic predisposition. Based on these considerations, successful investigation may well need a combination of proteomic biomarkers and information from other "omics" technologies.

The levels of individual metabolites can be considered as the final step in a biological process that is influenced by genetic and environmental factors, including, critically, nutritional intake.

The metabolome (from genome) is the complete set of metabolites in an organism, and metabolomics studies classify and quantify them individually in a biological fluid, cell culture, or tissue sample. Their levels, determined by analytical methods, supply information on how enzymes and the other functional proteins affect cellular homeostatic mechanisms [180]. Nutrients can interact directly with our body at the level of organs, cells, and molecules. They usually come in complex mixtures, where the amount of each compound and its interaction with multiple components are crucial, since they influence bioavailability and bioefficacy. Metabolomics allows systematic investigation of small organic molecules, and in conjunction with nutrigenomics establishes how those molecules can reflect the effects of different diets [182]. A key goal of nutritional metabolomics is to detect and identify all endogenous human metabolites and exogenous components consumed through food that are found at least transiently in human body fluids. The development of metabolite panels related to specific nutrition states would be able to characterize physiological and pathological conditions more exhaustively than dosing of a single molecule, and such information could be integrated with the data obtained with the other "omics" technologies [147,183-185].

A further approach that deserves to be mentioned in relation to the role of nutrients in health and disease is nutritional epigenetics, which endeavours to explore gene-diet interactions and can provide information on the role of nutrition in aging and ARD development $[137,208]$. Epigenetic traits are defined as heritable DNA modifications that regulate chromosome architecture and modulate gene expression, without changes in the underlying bp sequence, ultimately determining phenotype. 
DNA methylation and post-translational histone modifications are well-established levels of epigenetic regulation. Epigenetic phenomena are critical from embryonic life to old age, and epigenetic pattern aberrations are recognized as aetiological mechanisms in several ARDs including cancer, CVD and neurodegenerative disorders. Nutrients can act as sources of epigenetic modifications and can regulate the site where they take place. Nutrients involved in one carbon metabolism, i.e., folate, vitamin B12, vitamin B6, riboflavin, methionine, choline, and betaine, are involved in DNA methylation through modulation of the levels of the universal methyl donor $S$-adenosylmethionine and of the methyltransferase inhibitor S-adenosylhomocysteine. Other nutrients and bioactive components of food-e.g., retinoic acid, resveratrol, curcumin, sulphoraphane and tea polyphenols-affect epigenetic patterns by modulating the levels of $S$-adenosylmethionine and $S$-adenosylhomocysteine or the enzymes that catalyze DNA methylation and histone modifications. Aging and ARDs are associated with profound epigenetic changes, even though it is unclear whether such changes are programmatic or stochastic [209]. Future work in this field will need to characterize the epigenetic pattern of healthy aging, to learn which nutritional measures can contribute to maintain or achieve it.

A large number of metabolically active metabolites are produced by the microbiome, particularly the gut microbiome, which may be viewed as a complex organ capable of influencing host health. Recent studies suggest that it should actually be regarded as an "immune system" that can promote health but sometimes initiates disorders such as inflammatory bowel disease, metabolic syndrome, obesity-related disease, diabetes, liver disease and colorectal cancer [210]. Changes in the diet may exert profound effects on the microbiome and are capable of altering the overall bacterial composition. Interactions between the microbiome and the metabolism of dietary components such as phosphatidylcholine and carnitine have been reported to modulate the CVD risk [147]. Moreover, the microbiome could constitute a novel therapeutic opportunity, because in some cases it may be used to detect gut-related diseases earlier than conventional diagnostic workups. In the future, this information could be harnessed to stratify patients more accurately and for more effective treatment [210]. These research fields are still in their infancy. It is therefore critical to clarify the relationship among genetics, diet, microbiome, and health risk.

Finally, useful data are expected to come from systems biology, a highly cross-disciplinary approach to biology research; in turn, biochemical systems biology includes and combines genomics, biochemistry, and molecular biology integrating them with mathematical and computational analysis, engineering practices, and "omics" technologies such as transcriptomics, proteomics and metabolomics [211]. A number of experimental strategies are combining quantitative measurements of cell components (mRNA, proteins, and metabolites) using mathematical and computational models [147,212-232]. Such high-throughput technologies are providing a huge amount of functional genomic data that are expected to deliver breakthrough in aging research. According to Özdemir and colleagues, now that the goals and tasks of nutrition science and nutrigenomics have become clearly established, it would be desirable to achieve the integration of four key domains that are naturally connected-agrigenomics, nutrigenomics, nutriproteomics, and nutrimetabolomics-which address complementary issues in relation to individual differences in response to food-related environmental exposure. Although the knowledge and findings of these four omics have still failed to be integrated, they have a very high innovation potential. In the future, personalized nutrition interventions are expected to benefit from the integration of life sciences funding, research, and practice from "farm to clinic to supermarket to society," and from "genome to proteome to metabolome" [233].

\section{Molecular Pathological Epidemiology}

Epidemiological research typically investigates the factors that are associated with the overall risk of developing certain diseases, including the relationship between exposure and a disease entity in population-based cohorts, whereas pathology research traditionally explores aetiology, development, and histopathological and molecular characteristics to predict prognosis and response to treatment. The merging of the two approaches through the incorporation of molecular pathology into 
epidemiological research has created a new population health science field that straddles several research areas, which has been designated Molecular Pathological Epidemiology (MPE) [234,235]. Its close relationship to both aetiology and prognosis involves that MPE pursues to gain a greater understanding of how particular exposures influence disease risk through the search and evaluation for molecular pathological markers. Disease processes are influenced by a wide range of exogenous (e.g., acquired genetic and epigenetic alterations, diet, lifestyle, smoking, medications, microorganisms) as well as inherent factors (e.g., germline genetic variations, sex, ethnicity) that induce significant interindividual variability in all phases of the disease process [236]. Compared with conventional approaches, where patients diagnosed with similar symptoms or disease manifestations are assumed to make up a homogeneous group and to share similar causative factors, MPE employs molecular pathological signatures to refine patient categorization and identify subgroups that share more homogenous, to gain insight into disease heterogeneity respect to both aetiologies and pathogenic process. By this approach, the MPE multidisciplinary method explores whether exogenous and endogenous factors are associated with differential molecular signatures and disease subgroups [235,236].

The notion of MPE was first introduced by Ogino and Stampfer in a comment on a case-control study of body mass index (BMI) and the risk of colorectal cancer (CRC) in relation to tumour microsatellite instability (MSI) (MSI-high vs. microsatellite stability [MSS] status) [234,237]. The authors demonstrated that pre-diagnosis BMI was associated with an increased risk of developing CRC, and that the excess risk associated with BMI was limited to MSS tumours [237].

A large number of investigations have subsequently been identified as belonging to MPE. Several of these have identified links between diet, lifestyle, environmental exposure, and alteration of molecular patterns characterized as distinctive features of specific diseases.

Over the past few years, the molecular changes related to the risk of developing CRC have extensively been explored. MPE findings suggest that the effects on outcome of alterations in the WNT signalling pathway and cadherin-associated protein $\beta 1$ (CTNNB1 or $\beta$-catenin) are modified by BMI and physical activity. In particular, CTNNB1 activation was associated with longer CRC-specific survival and overall survival among obese patients, whereas post-diagnosis physical activity was associated with longer CRC-specific survival only for patients with negative nuclear CTNNB1 status [238]. According to another study, obesity and physical inactivity are associated with a higher risk of CTNNB1-negative CRC, but not of CTNNB1-positive CRC, suggesting that the energy balance and the metabolic state exert effects on a specific carcinogenesis pathway that is less likely to be dependent on WNT/CTNNB1 activation [239]. An important role for BMI has also been found in relation to tumour TP53 mutations, which are key factors in CRC development, and on fatty acid synthase (FASN), which is overexpressed in some colon cancers and in involved in the energy metabolism of fatty acids. MPE data support a dual role for TP53 alterations in cell-cycle deregulation and cell autonomy in relation to the energy balance [240], while FASN-negative and FASN-positive tumours have been reported to be associated with a significantly different CRC risk [241]. Moreover, an excess energy balance may influence the immune and inflammatory status, suggesting an association of BMI with a heightened CRC risk regardless of the level of the lymphocytic response to the tumour [242].

Dietary compounds affect specific pathways related to cancer development. High alcohol consumption increases the CRC risk because one-carbon metabolism triggers a DNA methylation reaction, which affects the $\mathrm{CpG}$ island methylator phenotype (CIMP), with tumour epigenetic features modulating the cancer risk [243,244]. Preclinical and epidemiological studies have provided evidence of a protective effect of vitamin D against CRC [245], whereas a higher calcium intake has been associated with a lower risk of developing CRC, especially distal colon cancer; the overall inverse association was linear and did not differ in relation to intake source [246]. Similarly, a high intake of marine $\omega-3$ polyunsaturated fatty acids ( $\omega$-3 PUFAs; including eicosapentaenoic acid, docosahexaenoic acid and docosapentaenoic acid) has been documented to have an antineoplastic action. An increased intake of marine $\omega-3$ PUFAs after CRC diagnosis may still confer benefits [247]. 
A large role for microRNAs has also been documented by MPE studies. The expression level of miR-21 is associated with a worse CRC clinical outcome [248], whereas let-7 family microRNAs suppress adaptive immune responses, contributing to immune evasion by the tumour [249]. Circulating miR-21-5p and miR-126-3p have been shown to play a role as dynamic biomarkers of systemic inflammatory/angiogenic status, and could have an even greater role in managing T2DM [250]. Furthermore, microRNAs have an established potential in the diagnosis and prognosis of several cancers and of pollution exposure [251]. For example, a pool of deregulated circulating and tissue microRNAs with biomarker and therapeutic potential has been identified in malignant mesothelioma, a lethal cancer related to asbestos exposure [252].

MPE findings have also linked leukocyte telomere length (LTL) and genetic variants in the telomerase reverse transcriptase gene region to the risk of pancreatic cancer [253]. LTL shortening is found in a number of ARDs, including T2DM. Analysis of its possible association with mortality was analyzed in this study. Recently, time-dependent mortality risk stratification has allowed demonstrating that T2DM duration and LTL combined with clinical parameters can provide additive prognostic information on mortality risk in these patients [8].

Finally, several lines of MPE evidence have confirmed the link between microbiota and disease. For instance, the abundance of Fusobacterium nucleatum, which increases gradually from the rectum to the caecum, reflects the pathogenic influence exerted by the gut microbiota on neoplastic and immune cells, and may promote CRC growth by inhibiting T-cell-mediated immune responses against the tumour. A greater amount of F. nucleatum DNA in CRC tissue is associated with shorter survival and may serve as a prognostic biomarker [254,255].

It is highly likely that the MPE data reviewed above can be harnessed to develop new disease prevention and early detection approaches, and that the molecules and pathways identified by MPE research can be used to devise new treatments by targeting altered regulatory mechanisms.

\section{Conclusions}

The notion that aging is a complex, multifactorial process depending on the interaction of genetic and environmental (including lifestyle) factors is widely shared. According to the latest scientific data, human genes are programmed for a lifespan of 120 years. Yet longevity is not merely embedded in the genes; rather, no less than 70\% of it needs to be conquered every day by a healthy diet and lifestyle.

The application of integrated omics approaches, together with increasingly detailed nutritional information have vastly improved the exploration and identification of relationships between lifestyle, diet, and health, including the interactions with genetic background and the microbiome, which actively influence them. These advances herald a growing role for nutrigenomics, since the development of personalized nutrition interventions is likely to induce large, appropriate and consistent changes in eating (and other lifestyle) behaviours, thus driving and supporting new prevention and therapeutic strategies, such as microbiome modulation.

Moreover, the evolving field of MPE, which incorporates traditional epidemiology and pathology research, is expected to elucidate how various exposures affect disease onset, transformation and progression. The remit of MPE clearly includes the investigation of the interactive effects of dietary/lifestyle exposures and tumour molecular features on tumour behaviour (prognosis/clinical outcome), so that, ideally, the effects of specific variables can be traced to a specific molecular subtype of cancer [235].

Acknowledgments: The authors are grateful to Word Designs (www.silviamodena.com) for the language revision.

Author Contributions: T.R. contributed literature review and critical revisions to the article, L.M. contributed literature review and critical revisions to the article, M.F.T. contributed critical revisions to the article and intellectual discussions, A.C. designed the study, coordinated the research and contributed to writing the article.

Conflicts of Interest: The authors declare no conflict of interest. 


\section{References}

1. National Research Council (U.S.) Committee on Population. Between Zeus and the Salmon; Wachter, K.W., Finch, C.E., Eds.; National Academies Press (U.S.): Washington, DC, USA, 1997.

2. Weinert, B.T.; Timiras, P.S. Invited review: Theories of aging. J. Appl. Physiol. 2003, 95, 1706-1716. [CrossRef] [PubMed]

3. Yang, J.; Huang, T.; Song, W.; Petralia, F.; Mobbs, C.V.; Zhang, B.; Zhao, Y.; Schadt, E.E.; Zhu, J.; Tu, Z. Discover the network mechanisms underlying the connections between aging and age-related diseases. Sci. Rep. 2016, 6, 32566. [CrossRef] [PubMed]

4. Srivastava, I.; Thukral, N.; Hasija, Y. Genetics of human age related disorders. Adv. Gerontol. Uspekhi Gerontol. 2015, 28, 228-247.

5. Pizza, V.; Agresta, A.; D'Acunto, C.W.; Festa, M.; Capasso, A. Neuroinflammation and ageing: Current theories and an overview of the data. Rev. Recent Clin. Trials 2011, 6, 189-203. [CrossRef] [PubMed]

6. Kowald, A.; Kirkwood, T.B. A network theory of ageing: The interactions of defective mitochondria, aberrant proteins, free radicals and scavengers in the ageing process. Mutat. Res. 1996, 316, 209-236. [CrossRef]

7. Von Zglinicki, T.; Martin-Ruiz, C.M. Telomeres as biomarkers for ageing and age-related diseases. Curr. Mol. Med. 2005, 5, 197-203. [CrossRef] [PubMed]

8. Bonfigli, A.R.; Spazzafumo, L.; Prattichizzo, F.; Bonafè, M.; Mensà, E.; Micolucci, L.; Giuliani, A.; Fabbietti, P.; Testa, R.; Boemi, M.; et al. Leukocyte telomere length and mortality risk in patients with type 2 diabetes. Oncotarget 2016, 7, 50835-50844. [CrossRef] [PubMed]

9. Olivieri, F.; Albertini, M.C.; Orciani, M.; Ceka, A.; Cricca, M.; Procopio, A.D.; Bonafè, M. DNA damage response (DDR) and senescence: Shuttled inflamma-miRNAs on the stage of inflamm-aging. Oncotarget 2015, 6, 35509-35521. [PubMed]

10. Maslov, A.Y.; Vijg, J. Genome instability, cancer and aging. Biochim. Biophys. Acta Gen. Subj. 2009, 1790, 963-969. [CrossRef] [PubMed]

11. Dai, D.-F.; Chiao, Y.; Marcinek, D.J.; Szeto, H.H.; Rabinovitch, P.S. Mitochondrial oxidative stress in aging and healthspan. Longev. Health 2014, 3, 6. [CrossRef] [PubMed]

12. Bhatti, J.S.; Bhatti, G.K.; Reddy, P.H. Mitochondrial dysfunction and oxidative stress in metabolic disorders-A step towards mitochondria based therapeutic strategies. Biochim. Biophys. Acta Mol. Basis Dis. 2016. [CrossRef] [PubMed]

13. Singhal, G.; Jaehne, E.J.; Corrigan, F.; Toben, C.; Baune, B.T. Inflammasomes in neuroinflammation and changes in brain function: A focused review. Front. Neurosci. 2014, 8, 315. [CrossRef] [PubMed]

14. Bessueille, L.; Magne, D. Inflammation: A culprit for vascular calcification in atherosclerosis and diabetes. Cell. Mol. Life Sci. 2015, 72, 2475-2489. [CrossRef] [PubMed]

15. Guarner, V.; Rubio-Ruiz, M.E. Low-grade systemic inflammation connects aging, metabolic syndrome and cardiovascular disease. Interdiscip. Top. Gerontol. 2015, 40, 99-106. [PubMed]

16. Franceschi, C.; Bonafè, M.; Valensin, S.; Olivieri, F.; de Luca, M.; Ottaviani, E.; de Benedictis, G. Inflamm-aging. An evolutionary perspective on immunosenescence. Ann. N. Y. Acad. Sci. 2000, 908, 244-254. [CrossRef] [PubMed]

17. De la Fuente, M.; Miquel, J. An update of the oxidation-inflammation theory of aging: The involvement of the immune system in oxi-inflamm-aging. Curr. Pharm. Des. 2009, 15, 3003-3026. [CrossRef] [PubMed]

18. Ricordi, C.; Garcia-Contreras, M.; Farnetti, S. Diet and inflammation: Possible effects on immunity, chronic diseases, and life span. J. Am. Coll. Nutr. 2015, 34, 10-13. [CrossRef] [PubMed]

19. Pelicci, P.G.; Migliaccio, E.; Giorgio, M.; Mele, S.; Pelicci, G.; Reboldi, P.; Pandolfi, P.P.; Lanfrancone, L. The p66shc adaptor protein controls oxidative stress response and life span in mammals. Nature 1999, 402, 309-313. [CrossRef] [PubMed]

20. Puca, A.A.; Daly, M.J.; Brewster, S.J.; Matise, T.C.; Barrett, J.; Shea-Drinkwater, M.; Kang, S.; Joyce, E.; Nicoli, J.; Benson, E.; et al. A genome-wide scan for linkage to human exceptional longevity identifies a locus on chromosome 4. Proc. Natl. Acad. Sci. USA 2001, 98, 10505-10508. [CrossRef] [PubMed]

21. Hayflick, L. The limited in vitro lifetime of human diploid cell strains. Exp. Cell Res. 1965, 37, 614-636. [CrossRef]

22. Judith, C. Cellular Senescence and Cell Death. In Physiological Basis of Aging and Geriatrics, 3rd ed.; Timiras, P.S., Ed.; CRC Press: Boca Raton, FL, USA, 2003; pp. 47-59. 
23. Blackburn, E.H. Telomere states and cell fates. Nature 2000, 408, 53-56. [CrossRef] [PubMed]

24. Kim, N.W.; Piatyszek, M.A.; Prowse, K.R.; Harley, C.B.; West, M.D.; Ho, P.L.; Coviello, G.M.; Wright, W.E.; Weinrich, S.L.; Shay, J.W. Specific association of human telomerase activity with immortal cells and cancer. Science 1994, 266, 2011-2015. [CrossRef] [PubMed]

25. Reddel, R.R. The role of senescence and immortalization in carcinogenesis. Carcinogenesis 2000, 21, 477-484. [CrossRef] [PubMed]

26. Ferrara, N.; Corbi, G.; Scarpa, D.; Rengo, G.; Longobardi, G.; Mazzella, F.; Cacciatore, F.; Rengo, F. Teorie dell'invecchiamento The aging theories. G. Gerontol. 2005, 53, 57-74.

27. Smith, R.G.; Betancourt, L.; Sun, Y. Molecular endocrinology and physiology of the aging central nervous system. Endocr. Rev. 2005, 26, 203-250. [CrossRef] [PubMed]

28. Pizza, V.; Agresta, A.; Iorio, E.L.; Capasso, A. Oxidative stress and aging: a clinical and biochemical study. Pharmacologyonline 2013, 2, 28-37.

29. Cannon, W.B. The Wisdom of the Body; W. W. Norton \& Company: New York, NY, USA, 1932.

30. McEwen, B.S. The End of Stress as We Know It; Joseph Henry Press: Washington, DC, USA, 2002.

31. Selye, H. The Stress of Life; McGraw-Hill: New York, NY, USA, 1976.

32. Nawata, H.; Yanase, T.; Goto, K.; Okabe, T.; Nomura, M.; Ashida, K.; Watanabe, T. Adrenopause. Horm. Res. 2004, 62, 110-114. [CrossRef] [PubMed]

33. Graham, D.; McLachlan, A. Declining melatonin levels and older people. How old is old? Neuro Endocrinol. Lett. 2004, 25, 415-418. [PubMed]

34. Arendt, J. Melatonin. Clin. Endocrinol. (Oxf.) 1988, 29, 205-229. [CrossRef] [PubMed]

35. Armstrong, S.M.; Redman, J.R. Melatonin: A chronobiotic with anti-aging properties? Med. Hypotheses 1991, 34, 300-309. [CrossRef]

36. Bondy, S.C.; Sharman, E.H. Melatonin and the aging brain. Neurochem. Int. 2007, 50, 571-580. [CrossRef] [PubMed]

37. Pierpaoli, W.; Regelson, W. Pineal control of aging: Effect of melatonin and pineal grafting on aging mice. Proc. Natl. Acad. Sci. USA 1994, 91, 787-791. [CrossRef] [PubMed]

38. Karasek, M. Melatonin, human aging, and age-related diseases. Exp. Gerontol. 2004, 39, 1723-1729. [CrossRef] [PubMed]

39. Rudman, D.; Feller, A.G.; Nagraj, H.S.; Gergans, G.A.; Lalitha, P.Y.; Goldberg, A.F.; Schlenker, R.A.; Cohn, L.; Rudman, I.W.; Mattson, D.E. Effects of human growth hormone in men over 60 years old. N. Engl. J. Med. 1990, 323, 1-6. [CrossRef] [PubMed]

40. Nass, R.; Park, J.; Thorner, M.O. Growth hormone supplementation in the elderly. Endocrinol. Metab. Clin. N. Am. 2007, 36, 233-245. [CrossRef] [PubMed]

41. Snyder, P.J.; Peachey, H.; Hannoush, P.; Berlin, J.A.; Loh, L.; Lenrow, D.A.; Holmes, J.H.; Dlewati, A.; Santanna, J.; Rosen, C.J.; et al. Effect of testosterone treatment on body composition and muscle strength in men over 65 years of age. J. Clin. Endocrinol. Metab. 1999, 84, 2647-2653. [CrossRef] [PubMed]

42. Stoll, B.A. Dietary supplements of dehydroepiandrosterone in relation to breast cancer risk. Eur. J. Clin. Nutr. 1999, 53, 771-775. [CrossRef] [PubMed]

43. Effros, R.B. From Hayflick to Walford: The role of T cell replicative senescence in human aging. Exp. Gerontol. 2004, 39, 885-890. [CrossRef] [PubMed]

44. Zhang, H.; Puleston, D.J.; Simon, A.K. Autophagy and immune senescence. Trends Mol. Med. 2016, 22, 671-686. [CrossRef] [PubMed]

45. Gerli, R.; Paganelli, R.; Cossarizza, A.; Muscat, C.; Piccolo, G.; Barbieri, D.; Mariotti, S.; Monti, D.; Bistoni, O.; Raiola, E.; et al. Long-term immunologic effects of thymectomy in patients with myasthenia gravis. J. Allergy Clin. Immunol. 1999, 103, 865-872. [CrossRef]

46. Effros, R.B. Ageing and the immune system. Novartis Found. Symp. 2001, 235, 146-149.

47. Fagnoni, F.F.; Vescovini, R.; Mazzola, M.; Bologna, G.; Nigro, E.; Lavagetto, G.; Franceschi, C.; Passeri, M.; Sansoni, P. Expansion of cytotoxic CD8+ CD28- T cells in healthy ageing people, including centenarians. Immunology 1996, 88, 501-507. [CrossRef] [PubMed]

48. Timm, J.A.; Thoman, M.L. Maturation of CD4+ lymphocytes in the aged microenvironment results in a memory-enriched population. J. Immunol. 1999, 162, 711-717. [PubMed] 
49. Effros, R.B. Long-term immunological memory against viruses. Mech. Ageing Dev. 2000, 121, $161-171$. [CrossRef]

50. Wikby, A.; Johansson, B.; Olsson, J.; Löfgren, S.; Nilsson, B.O.; Ferguson, F. Expansions of peripheral blood CD8 T-lymphocyte subpopulations and an association with cytomegalovirus seropositivity in the elderly: The Swedish NONA immune study. Exp. Gerontol. 2002, 37, 445-453. [CrossRef]

51. Pawelec, G.; Ouyang, Q.; Wagner, W.; Biol, D.; Wikby, A. Pathways to a robust immune response in the elderly. Immunol. Allergy Clin. N. Am. 2003, 23, 1-13. [CrossRef]

52. Bonafè, M.; Valensin, S.; Gianni, W.; Marigliano, V.; Franceschi, C. The unexpected contribution of immunosenescence to the leveling off of cancer incidence and mortality in the oldest old. Crit. Rev. Oncol. Hematol. 2001, 39, 227-233. [CrossRef]

53. Pahlavani, M.A. T cell signaling: Effect of age. Front. Biosci. 1998, 3, D1120-D1133. [CrossRef] [PubMed]

54. Franceschi, C.; Monti, D.; Sansoni, P.; Cossarizza, A. The immunology of exceptional individuals: The lesson of centenarians. Immunol. Today 1995, 16, 12-16. [CrossRef]

55. Sansoni, P.; Cossarizza, A.; Brianti, V.; Fagnoni, F.; Snelli, G.; Monti, D.; Marcato, A.; Passeri, G.; Ortolani, C.; Forti, E. Lymphocyte subsets and natural killer cell activity in healthy old people and centenarians. Blood 1993, 82, 2767-2773. [PubMed]

56. Franceschi, C.; Monti, D.; Barbieri, D.; Grassilli, E.; Troiano, L.; Salvioli, S.; Negro, P.; Capri, M.; Guido, M.; Azzi, R.; et al. Immunosenescence in Humans: Deterioration or Remodelling? Int. Rev. Immunol. 1995, 12, 57-74. [CrossRef] [PubMed]

57. Ogata, K.; Yokose, N.; Tamura, H.; An, E.; Nakamura, K.; Dan, K.; Nomura, T. Natural killer cells in the late decades of human life. Clin. Immunol. Immunopathol. 1997, 84, 269-275. [CrossRef] [PubMed]

58. Remarque, E.; Pawelec, G. T-cell immunosenescence and its clinical relevance in man. Rev. Clin. Gerontol. 1998, 8, 5-14. [CrossRef]

59. Kourilsky, P.; Truffa-Bachi, P. Cytokine fields and the polarization of the immune response. Trends Immunol. 2001, 22, 502-509. [CrossRef]

60. Forsey, R.J.; Thompson, J.M.; Ernerudh, J.; Hurst, T.L.; Strindhall, J.; Johansson, B.; Nilsson, B.-O.; Wikby, A. Plasma cytokine profiles in elderly humans. Mech. Ageing Dev. 2003, 124, 487-493. [CrossRef]

61. Kerr, J.F.; Wyllie, A.H.; Currie, A.R. Apoptosis: A basic biological phenomenon with wide-ranging implications in tissue kinetics. Br. J. Cancer 1972, 26, 239-257. [CrossRef] [PubMed]

62. Akbar, A.N.; Salmon, M. Cellular environments and apoptosis: Tissue microenvironments control activated T-cell death. Immunol. Today 1997, 18, 72-76. [CrossRef]

63. Krammer, P.H. CD95's deadly mission in the immune system. Nature 2000, 407, 789-795. [CrossRef] [PubMed]

64. Gupta, S. Molecular steps of death receptor and mitochondrial pathways of apoptosis. Life Sci. 2001, 69, 2957-2964. [CrossRef]

65. Hengartner, M.O. The biochemistry of apoptosis. Nature 2000, 407, 770-776. [CrossRef] [PubMed]

66. Jäättelä, M.; Tschopp, J. Caspase-independent cell death in T lymphocytes. Nat. Immunol. 2003, 4, 416-423. [CrossRef] [PubMed]

67. Franceschi, C.; Valensin, S.; Bonafè, M.; Paolisso, G.; Yashin, A.I.; Monti, D.; De Benedictis, G. The network and the remodeling theories of aging: Historical background and new perspectives. Exp. Gerontol. 2000, 35, 879-896. [CrossRef]

68. De Martinis, M.; Franceschi, C.; Monti, D.; Ginaldi, L. Apoptosis remodeling in immunosenescence: Implications for strategies to delay ageing. Curr. Med. Chem. 2007, 14, 1389-1397. [CrossRef] [PubMed]

69. Franceschi, C.; Bonafè, M.; Valensin, S. Human immunosenescence: The prevailing of innate immunity, the failing of clonotypic immunity, and the filling of immunological space. Vaccine 2000, 18, 1717-1720. [CrossRef]

70. Finkel, T.; Holbrook, N.J. Oxidants, oxidative stress and the biology of ageing. Nature 2000, 408, $239-247$. [CrossRef] [PubMed]

71. Franceschi, C. Cell proliferation, cell death and aging. Aging (Milano) 1989, 1, 3-15. [CrossRef] [PubMed]

72. Franceschi, C.; Ottaviani, E. Stress, inflammation and natural immunity in the aging process: A new theory. Aging (Milano) 1997, 9, 30-31. [CrossRef] [PubMed]

73. Salvioli, S.; Capri, M.; Valensin, S.; Tieri, P.; Monti, D.; Ottaviani, E.; Franceschi, C. Inflamm-aging, cytokines and aging: State of the art, new hypotheses on the role of mitochondria and new perspectives from systems biology. Curr. Pharm. Des. 2006, 12, 3161-3171. [CrossRef] [PubMed] 
74. De Martinis, M.; Franceschi, C.; Monti, D.; Ginaldi, L. Inflamm-ageing and lifelong antigenic load as major determinants of ageing rate and longevity. FEBS Lett. 2005, 579, 2035-2039. [CrossRef] [PubMed]

75. Fagiolo, U.; Cossarizza, A.; Scala, E.; Fanales-Belasio, E.; Ortolani, C.; Cozzi, E.; Monti, D.; Franceschi, C.; Paganelli, R. Increased cytokine production in mononuclear cells of healthy elderly people. Eur. J. Immunol. 1993, 23, 2375-2378. [CrossRef] [PubMed]

76. Lio, D.; Scola, L.; Crivello, A.; Colonna-Romano, G.; Candore, G.; Bonafé, M.; Cavallone, L.; Marchegiani, F.; Olivieri, F.; Franceschi, C.; et al. Inflammation, genetics, and longevity: Further studies on the protective effects in men of IL-10-1082 promoter SNP and its interaction with TNF- $\alpha-308$ promoter SNP. J. Med. Genet. 2003, 40, 296-299. [CrossRef] [PubMed]

77. Candore, G.; Colonna-Romano, G.; Balistreri, C.R.; Carlo, D.D.; Grimaldi, M.P.; Listì, F.; Nuzzo, D.; Vasto, S.; Lio, D.; Caruso, C. Biology of Longevity: Role of the Innate Immune System. Rejuvenation Res. 2006, 9, 143-148. [CrossRef] [PubMed]

78. Giunta, S. Is inflammaging an auto[innate]immunity subclinical syndrome? Immun. Ageing 2006, 3, 12. [CrossRef] [PubMed]

79. Campisi, J.; d'Adda di Fagagna, F. Cellular senescence: When bad things happen to good cells. Nat. Rev. Mol. Cell Biol. 2007, 8, 729-740. [CrossRef] [PubMed]

80. Childs, B.G.; Durik, M.; Baker, D.J.; van Deursen, J.M. Cellular senescence in aging and age-related disease: From mechanisms to therapy. Nat. Med. 2015, 21, 1424-1435. [CrossRef] [PubMed]

81. Franceschi, C.; Motta, L.; Valensin, S.; Rapisarda, R.; Franzone, A.; Berardelli, M.; Motta, M.; Monti, D.; Bonafè, M.; Ferrucci, L.; et al. Do men and women follow different trajectories to reach extreme longevity? Italian Multicenter Study on Centenarians (IMUSCE). Aging (Milano) 2000, 12, 77-84. [PubMed]

82. Ginaldi, L.; de Martinis, M.; Monti, D.; Franceschi, C. The immune system in the elderly: Activation-induced and damage-induced apoptosis. Immunol. Res. 2004, 30, 81-94. [CrossRef]

83. Bonafè, M.; Olivieri, F.; Cavallone, L.; Giovagnetti, S.; Mayegiani, F.; Cardelli, M.; Pieri, C.; Marra, M.; Antonicelli, R.; Lisa, R.; et al. A gender-Dependent genetic predisposition to produce high levels of IL-6 is detrimental for longevity. Eur. J. Immunol. 2001, 31, 2357-2361. [CrossRef]

84. Capri, M.; Salvioli, S.; Sevini, F.; Valensin, S.; Celani, L.; Monti, D.; Pawelec, G.; de Benedictis, G.; Gonos, E.S.; Franceschi, C. The Genetics of Human Longevity. Ann. N. Y. Acad. Sci. 2006, 1067, 252-263. [CrossRef] [PubMed]

85. Franceschi, C.; Bezrukov, V.; Blanché, H.; Bolund, L.; Christensen, K.; de Benedictis, G.; Deiana, L.; Gonos, E.; Hervonen, A.; Yang, H.; et al. Genetics of healthy aging in Europe: The EU-integrated project GEHA (GEnetics of Healthy Aging). Ann. N. Y. Acad. Sci. 2007, 1100, 21-45. [CrossRef] [PubMed]

86. Khan, N.; Shariff, N.; Cobbold, M.; Bruton, R.; Ainsworth, J.A.; Sinclair, A.J.; Nayak, L.; Moss, P.A.H. Cytomegalovirus seropositivity drives the CD8 T cell repertoire toward greater clonality in healthy elderly individuals. J. Immunol. 2002, 169, 1984-1992. [CrossRef] [PubMed]

87. Ouyang, Q.; Wagner, W.M.; Walter, S.; Müller, C.A.; Wikby, A.; Aubert, G.; Klatt, T.; Stevanovic, S.; Dodi, T.; Pawelec, G. An age-related increase in the number of CD8+ T cells carrying receptors for an immunodominant Epstein-Barr virus (EBV) epitope is counteracted by a decreased frequency of their antigen-specific responsiveness. Mech. Ageing Dev. 2003, 124, 477-485. [CrossRef]

88. Pawelec, G.; Akbar, A.; Caruso, C.; Solana, R.; Grubeck-Loebenstein, B.; Wikby, A. Human immunosenescence: Is it infectious? Immunol. Rev. 2005, 205, 257-268. [CrossRef] [PubMed]

89. Vescovini, R.; Telera, A.; Fagnoni, F.F.; Biasini, C.; Medici, M.C.; Valcavi, P.; di Pede, P.; Lucchini, G.; Zanlari, L.; Passeri, G.; et al. Different contribution of EBV and CMV infections in very long-term carriers to age-related alterations of CD8+ T cells. Exp. Gerontol. 2004, 39, 1233-1243. [CrossRef] [PubMed]

90. Bürkle, A.; Caselli, G.; Franceschi, C.; Mariani, E.; Sansoni, P.; Santoni, A.; Vecchio, G.; Witkowski, J.M.; Caruso, C. Pathophysiology of ageing, longevity and age related diseases. Immun. Ageing 2007, 4, 4. [CrossRef] [PubMed]

91. Kammerman, E.M.; Neumann, D.M.; Ball, M.J.; Lukiw, W.; Hill, J.M. Senile plaques in Alzheimer's diseased brains: possible association of beta-amyloid with herpes simplex virus type 1 (HSV-1) L-particles. Med. Hypotheses 2006, 66, 294-299. [CrossRef] [PubMed]

92. Itzhaki, R. Herpes simplex virus type 1, apolipoprotein E and Alzheimer' disease. Herpes 2004, 11, 77A-82A. [PubMed] 
93. Letenneur, L.; Pérès, K.; Fleury, H.; Garrigue, I.; Barberger-Gateau, P.; Helmer, C.; Orgogozo, J.-M.; Gauthier, S.; Dartigues, J.-F. Seropositivity to herpes simplex virus antibodies and risk of Alzheimer's disease: A population-based cohort study. PLoS ONE 2008, 3, e3637. [CrossRef] [PubMed]

94. Malaquin, N.; Carrier-Leclerc, A.; Dessureault, M.; Rodier, F. DDR-mediated crosstalk between DNAdamaged cells and their microenvironment. Front. Genet. 2015, 6, 94. [CrossRef] [PubMed]

95. Prattichizzo, F.; Bonafè, M.; Ceka, A.; Giuliani, A.; Rippo, M.R.; Re, M.; Antonicelli, R.; Procopio, A.D.; Olivieri, F. Endothelial Cell Senescence and Inflammaging: MicroRNAs as Biomarkers and Innovative Therapeutic Tools. Curr. Drug Targets 2016, 17, 388-397. [CrossRef] [PubMed]

96. Cesari, M.; Penninx, B.W.J.H.; Pahor, M.; Lauretani, F.; Corsi, A.M.; Rhys Williams, G.; Guralnik, J.M.; Ferrucci, L. Inflammatory markers and physical performance in older persons: The InCHIANTI study. J. Gerontol. A Biol. Sci. Med. Sci. 2004, 59, 242-248. [CrossRef] [PubMed]

97. Rowshani, A.T.; Bemelman, F.J.; van Leeuwen, E.M.M.; van Lier, R.A.W.; ten Berge, I.J.M. Clinical and immunologic aspects of cytomegalovirus infection in solid organ transplant recipients. Transplantation 2005, 79, 381-386. [CrossRef] [PubMed]

98. Salvioli, S.; Olivieri, F.; Marchegiani, F.; Cardelli, M.; Santoro, A.; Bellavista, E.; Mishto, M.; Invidia, L.; Capri, M.; Valensin, S.; et al. Genes, ageing and longevity in humans: Problems, advantages and perspectives. Free Radic. Res. 2006, 40, 1303-1323. [CrossRef] [PubMed]

99. Carrieri, G.; Marzi, E.; Olivieri, F.; Marchegiani, F.; Cavallone, L.; Cardelli, M.; Giovagnetti, S.; Stecconi, R.; Molendini, C.; Trapassi, C.; et al. The G/C915 polymorphism of transforming growth factor beta1 is associated with human longevity: A study in Italian centenarians. Aging Cell 2004, 3, 443-448. [CrossRef] [PubMed]

100. Caruso, C.; Lio, D.; Cavallone, L.; Franceschi, C. Aging, longevity, inflammation, and cancer. Ann. N. Y. Acad. Sci. 2004, 1028, 1-13. [CrossRef] [PubMed]

101. Franceschi, C.; Capri, M.; Monti, D.; Giunta, S.; Olivieri, F.; Sevini, F.; Panourgia, M.P.; Invidia, L.; Celani, L.; Scurti, M.; et al. Inflammaging and anti-inflammaging: A systemic perspective on aging and longevity emerged from studies in humans. Mech. Ageing Dev. 2007, 128, 92-105. [CrossRef] [PubMed]

102. Scannapieco, F.A.; Cantos, A. Oral inflammation and infection, and chronic medical diseases: Implications for the elderly. Periodontology 2016, 72, 153-175. [CrossRef] [PubMed]

103. Gloeckler Ries, L.A.; Reichman, M.E.; Lewis, D.R.; Hankey, B.F.; Edwards, B.K. Cancer survival and incidence from the Surveillance, Epidemiology, and End Results (SEER) program. Oncologist 2003, 8, 541-552. [CrossRef] [PubMed]

104. Serrano, M.; Blasco, M.A. Cancer and ageing: Convergent and divergent mechanisms. Nat. Rev. Mol. Cell Biol. 2007, 8, 715-722. [CrossRef] [PubMed]

105. Finkel, T.; Serrano, M.; Blasco, M.A. The common biology of cancer and ageing. Nature 2007, 448, 767-774. [CrossRef] [PubMed]

106. Derhovanessian, E.; Solana, R.; Larbi, A.; Pawelec, G. Immunity, ageing and cancer. Immun. Ageing $2008,5,11$. [CrossRef] [PubMed]

107. Thun, M.J.; Henley, S.J.; Gansler, T. Inflammation and cancer: An epidemiological perspective. Novartis Found. Symp. 2004, 256, 266-269.

108. Macarthur, M.; Hold, G.L.; El-Omar, E.M. Inflammation and Cancer II. Role of chronic inflammation and cytokine gene polymorphisms in the pathogenesis of gastrointestinal malignancy. Am. J. Physiol. Gastrointest. Liver Physiol. 2004, 286, G515-G520. [CrossRef] [PubMed]

109. Erlinger, T.P.; Platz, E.A.; Rifai, N.; Helzlsouer, K.J. C-Reactive protein and the risk of incident colorectal cancer. JAMA 2004, 291, 585. [CrossRef] [PubMed]

110. Hussain, S.P.; Hofseth, L.J.; Harris, C.C. Radical causes of cancer. Nat. Rev. Cancer 2003, 3, 276-285. [CrossRef] [PubMed]

111. Szlosarek, P.W.; Balkwill, F.R. Tumour necrosis factor alpha: A potential target for the therapy of solid tumours. Lancet. Oncol. 2003, 4, 565-573. [CrossRef]

112. Palma, G.; D'Aiuto, M.; Petrillo, A.; Dallemagne, P.; Sinicropi, M.S.; Rodriquez, M.; Longo, P.; Mariconda, A.L.; Arra, C.; De Martino, F.; et al. Targeting STAT3 in cancer inhibition. Pharmacologyonline 2015, 1, 50-66. 
113. Olivieri, F.; Rippo, M.R.; Monsurrò, V.; Salvioli, S.; Capri, M.; Procopio, A.D.; Franceschi, C. MicroRNAs linking inflamm-aging, cellular senescence and cancer. Ageing Res. Rev. 2013, 12, 1056-1068. [CrossRef] [PubMed]

114. Epstein, F.H.; Ross, R. Atherosclerosis-An Inflammatory Disease. N. Engl. J. Med. 1999, 340, $115-126$. [CrossRef] [PubMed]

115. Goate, A.; Chartier-Harlin, M.-C.; Mullan, M.; Brown, J.; Crawford, F.; Fidani, L.; Giuffra, L.; Haynes, A.; Irving, N.; James, L.; et al. Segregation of a missense mutation in the amyloid precursor protein gene with familial Alzheimer's disease. Nature 1991, 349, 704-706. [CrossRef] [PubMed]

116. Sherrington, R.; Rogaev, E.I.; Liang, Y.; Rogaeva, E.A.; Levesque, G.; Ikeda, M.; Chi, H.; Lin, C.; Li, G.; Holman, K.; et al. Cloning of a gene bearing missense mutations in early-onset familial Alzheimer's disease. Nature 1995, 375, 754-760. [CrossRef] [PubMed]

117. Rogaev, E.I.; Sherrington, R.; Rogaeva, E.A.; Levesque, G.; Ikeda, M.; Liang, Y.; Chi, H.; Lin, C.; Holman, K.; Tsuda, T.; et al. Familial Alzheimer's disease in kindreds with missense mutations in a gene on chromosome 1 related to the Alzheimer's disease type 3 gene. Nature 1995, 376, 775-778. [CrossRef] [PubMed]

118. Solerte, S.B.; Fioravanti, M.; Pascale, A.; Ferrari, E.; Govoni, S.; Battaini, F. Increased natural killer cell cytotoxicity in Alzheimer's disease may involve protein kinase C dysregulation. Neurobiol. Aging 1998, 19, 191-199. [CrossRef]

119. Solerte, S.B.; Fioravanti, M.; Vignati, G.; Giustina, A.; Cravello, L.; Ferrari, E. Dehydroepiandrosterone sulfate enhances natural killer cell cytotoxicity in humans via locally generated immunoreactive insulin-like growth factor I. J. Clin. Endocrinol. Metab. 1999, 84, 3260-3267. [CrossRef] [PubMed]

120. Licastro, F.; Pedrini, S.; Caputo, L.; Annoni, G.; Davis, L.J.; Ferri, C.; Casadei, V.; Grimaldi, L.M. Increased plasma levels of interleukin-1, interleukin-6 and alpha-1-antichymotrypsin in patients with Alzheimer's disease: Peripheral inflammation or signals from the brain? J. Neuroimmunol. 2000, 103, 97-102. [CrossRef]

121. Licastro, F.; Pedrini, S.; Ferri, C.; Casadei, V.; Govoni, M.; Pession, A.; Sciacca, F.L.; Veglia, F.; Annoni, G.; Bonafè, M.; et al. Gene polymorphism affecting alpha1-antichymotrypsin and interleukin-1 plasma levels increases Alzheimer's disease risk. Ann. Neurol. 2000, 48, 388-391. [CrossRef]

122. De Luigi, A.; Fragiacomo, C.; Lucca, U.; Quadri, P.; Tettamanti, M.; Grazia De Simoni, M. Inflammatory markers in Alzheimer's disease and multi-infarct dementia. Mech. Ageing Dev. 2001, 122, 1985-1995. [CrossRef]

123. Licastro, F.; Chiappelli, M. Brain immune responses cognitive decline and dementia: Relationship with phenotype expression and genetic background. Mech. Ageing Dev. 2003, 124, 539-548. [CrossRef]

124. Mukherjee, P.; Pasinetti, G.M. The role of complement anaphylatoxin C5a in neurodegeneration: Implications in Alzheimer's disease. J. Neuroimmunol. 2000, 105, 124-130. [CrossRef]

125. Tan, J.; Town, T.; Paris, D.; Mori, T.; Suo, Z.; Crawford, F.; Mattson, M.P.; Flavell, R.A.; Mullan, M. Microglial activation resulting from CD40-CD40L interaction after $\beta$-amyloid stimulation. Science 1999, 286, 2352-2355. [CrossRef] [PubMed]

126. Tuppo, E.E.; Arias, H.R. The role of inflammation in Alzheimer's disease. Int. J. Biochem. Cell Biol. 2005, 37, 289-305. [CrossRef] [PubMed]

127. In'T Veld, B.A.; Ruitenberg, A.; Hofman, A.; Launer, L.J.; van Duijn, C.M.; Stijnen, T.; Breteler, M.M.B.; Stricker, B.H.C. Nonsteroidal antiinflammatory drugs and the risk of alzheimer's disease. N. Engl. J. Med. 2001, 345, 1515-1521. [CrossRef] [PubMed]

128. Licastro, F.; Grimaldi, L.M.E.; Bonafè, M.; Martina, C.; Olivieri, F.; Cavallone, L.; Giovanietti, S.; Masliah, E.; Franceschi, C. Interleukin-6 gene alleles affect the risk of Alzheimer's disease and levels of the cytokine in blood and brain. Neurobiol. Aging 2003, 24, 921-926. [CrossRef]

129. Candore, G.; Balistreri, C.R.; Colonna-Romano, G.; Lio, D.; Caruso, C. Major histocompatibility complex and sporadic Alzheimer's disease: A critical reappraisal. Exp. Gerontol. 2004, 39, 645-652. [CrossRef] [PubMed]

130. Akiyama, H.; Barger, S.; Barnum, S.; Bradt, B.; Bauer, J.; Cole, G.M.; Cooper, N.R.; Eikelenboom, P.; Emmerling, M.; Fiebich, B.L.; et al. Inflammation and Alzheimer's disease. Neurobiol. Aging 2000, 21, 383-421. [CrossRef]

131. Scola, L.; Licastro, F.; Chiappelli, M.; Franceschi, C.; Grimaldi, L.M.; Crivello, A.; Colonna-Romano, G.; Candore, G.; Lio, D.; Caruso, C. Allele frequencies of $+874 \mathrm{~T} \rightarrow$ A single nucleotide polymorphism at the first intron of IFN-gamma gene in Alzheimer's disease patients. Aging Clin. Exp. Res. 2003, 15, 292-295. [CrossRef] [PubMed] 
132. Lio, D.; Licastro, F.; Scola, L.; Chiappelli, M.; Grimaldi, L.M.; Crivello, A.; Colonna-Romano, G.; Candore, G.; Franceschi, C.; Caruso, C. Interleukin-10 promoter polymorphism in sporadic Alzheimer's disease. Genes Immun. 2003, 4, 234-238. [CrossRef] [PubMed]

133. McGeer, P.L.; McGeer, E.G. Polymorphisms in inflammatory genes and the risk of Alzheimer disease. Arch. Neurol. 2001, 58, 1790-1792. [CrossRef] [PubMed]

134. Licastro, F.; Candore, G.; Lio, D.; Porcellini, E.; Colonna-Romano, G.; Franceschi, C.; Caruso, C. Innate immunity and inflammation in ageing: A key for understanding age-related diseases. Immun. Ageing 2005, 2, 8. [CrossRef] [PubMed]

135. Ordovas, J.M.; Corella, D. Nutritional genomics. Annu. Rev. Genom. Hum. Genet. 2004, 5, 71-118. [CrossRef] [PubMed]

136. Armstrong, B.; Doll, R. Environmental factors and cancer incidence and mortality in different countries, with special reference to dietary practices. Int. J. Cancer 1975, 15, 617-631. [CrossRef] [PubMed]

137. Bacalini, M.G.; Friso, S.; Olivieri, F.; Pirazzini, C.; Giuliani, C.; Capri, M.; Santoro, A.; Franceschi, C.; Garagnani, P. Present and future of anti-ageing epigenetic diets. Mech. Ageing Dev. 2014, 136-137, 101-115. [CrossRef] [PubMed]

138. Jeffery, I.B.; O'Toole, P.W. Diet-microbiota interactions and their implications for healthy living. Nutrients 2013, 5, 234-252. [CrossRef] [PubMed]

139. Neuhouser, M.L.; Patterson, R.E.; King, I.B.; Horner, N.K.; Lampe, J.W. Selected nutritional biomarkers predict diet quality. Public Health Nutr. 2003, 6, 703-709. [CrossRef] [PubMed]

140. Eilat-Adar, S.; Goldbourt, U. Nutritional recommendations for preventing coronary heart disease in women: Evidence concerning whole foods and supplements. Nutr. Metab. Cardiovasc. Dis. 2010, 20, 459-466. [CrossRef] [PubMed]

141. Milner, J.A. Molecular targets for bioactive food components. J. Nutr. 2004, 134, 2492S-2498S. [PubMed]

142. Lee, S.-A. Gene-Diet Interaction on Cancer Risk in Epidemiological Studies. J. Prev. Med. Public Health 2009, 42, 360. [CrossRef] [PubMed]

143. Roberts, M.A.; Mutch, D.M.; German, J.B. Genomics: Food and nutrition. Curr. Opin. Biotechnol. 2001, 12, 516-522. [CrossRef]

144. Ostan, R.; Lanzarini, C.; Pini, E.; Scurti, M.; Vianello, D.; Bertarelli, C.; Fabbri, C.; Izzi, M.; Palmas, G.; Biondi, F.; et al. Inflammaging and cancer: A challenge for the Mediterranean diet. Nutrients 2015, 7, 2589-2621. [CrossRef] [PubMed]

145. Berendsen, A.; Santoro, A.; Pini, E.; Cevenini, E.; Ostan, R.; Pietruszka, B.; Rolf, K.; Cano, N.; Caille, A.; Lyon-Belgy, N.; et al. Reprint of: A parallel randomized trial on the effect of a healthful diet on inflammageing and its consequences in European elderly people: Design of the NU-AGE dietary intervention study. Mech. Ageing Dev. 2014, 136-137, 14-21. [CrossRef] [PubMed]

146. Fenech, M.; El-Sohemy, A.; Cahill, L.; Ferguson, L.R.; French, T.-A.C.; Tai, E.S.; Milner, J.; Koh, W.-P.; Xie, L.; Zucker, M.; et al. Nutrigenetics and nutrigenomics: Viewpoints on the current status and applications in nutrition research and practice. J. Nutrigenet. Nutrigenom. 2011, 4, 69-89. [CrossRef] [PubMed]

147. Ferguson, J.F.; Allayee, H.; Gerszten, R.E.; Ideraabdullah, F.; Kris-Etherton, P.M.; Ordovás, J.M.; Rimm, E.B.; Wang, T.J.; Bennett, B.J. American Heart Association Council on Functional Genomics and Translational Biology, Council on Epidemiology and Prevention, and Stroke Council Nutrigenomics, the Microbiome, and Gene-Environment Interactions: New Directions in Cardiovascular Disease Research, Prevention, and Treatment: A Scientific Statement From the American Heart Association. Circ. Cardiovasc. Genet. 2016, 9, 291-313. [PubMed]

148. Preuss, C.; Das, M.K.; Pathak, Y.V. Genomics and natural products: Role of bioinformatics and recent patents. Recent Pat. Biotechnol. 2014, 8, 144-151. [CrossRef] [PubMed]

149. Evans, W.E.; Johnson, J.A. Pharmacogenomics: The inherited basis for interindividual differences in drug response. Annu. Rev. Genom. Hum. Genet. 2001, 2, 9-39. [CrossRef] [PubMed]

150. Evans, W.E.; McLeod, H.L.; McLeod, H.L. Pharmacogenomics-drug disposition, drug targets, and side effects. N. Engl. J. Med. 2003, 348, 538-549. [PubMed]

151. Brouwer, I.A.; Zock, P.L.; van Amelsvoort, L.G.; Katan, M.B.; Schouten, E.G. Association between $n$-3 fatty acid status in blood and electrocardiographic predictors of arrhythmia risk in healthy volunteers. Am. J. Cardiol. 2002, 89, 629-631. [CrossRef] 
152. Sacks, F.M.; Katan, M. Randomized clinical trials on the effects of dietary fat and carbohydrate on plasma lipoproteins and cardiovascular disease. Am. J. Med. 2002, 113, 13S-24S. [CrossRef]

153. Ohlsson, L. Dairy products and plasma cholesterol levels. Food Nutr. Res. 2010, 53, 105-110. [CrossRef] [PubMed]

154. Francis, G.A.; Fayard, E.; Picard, F.; Auwerx, J. Nuclear Receptors and the Control of Metabolism. Annu. Rev. Physiol. 2003, 65, 261-311. [CrossRef] [PubMed]

155. Willett, W.C. Nutritional epidemiology issues in chronic disease at the turn of the century. Epidemiol. Rev. 2000, 22, 82-86. [CrossRef] [PubMed]

156. Churchill, G.A. Fundamentals of experimental design for cDNA microarrays. Nat. Genet. 2002, 32, 490-495. [CrossRef] [PubMed]

157. Lee, C.-K.; Allison, D.B.; Brand, J.; Weindruch, R.; Prolla, T.A. Transcriptional profiles associated with aging and middle age-onset caloric restriction in mouse hearts. Proc. Natl. Acad. Sci. USA 2002, 99, 14988-14993. [CrossRef] [PubMed]

158. Cao, S.X.; Dhahbi, J.M.; Mote, P.L.; Spindler, S.R. Genomic profiling of short- and long-term caloric restriction effects in the liver of aging mice. Proc. Natl. Acad. Sci. USA 2001, 98, 10630-10635. [CrossRef] [PubMed]

159. Xiao, J.; Gregersen, S.; Kruhøffer, M.; Pedersen, S.B.; Ørntoft, T.F.; Hermansen, K. The effect of chronic exposure to fatty acids on gene expression in clonal insulin-producing cells: Studies using high density oligonucleotide microarray. Endocrinology 2001, 142, 4777-4784. [CrossRef] [PubMed]

160. Park, J.-H.; Ahn, J.; Kim, S.; Kwon, D.Y.; Ha, T.Y. Murine hepatic miRNAs expression and regulation of gene expression in diet-induced obese mice. Mol. Cells 2011, 31, 33-38. [CrossRef] [PubMed]

161. Reed, B.D.; Charos, A.E.; Szekely, A.M.; Weissman, S.M.; Snyder, M. Genome-wide occupancy of SREBP1 and its partners NFY and SP1 reveals novel functional roles and combinatorial regulation of distinct classes of genes. PLoS Genet. 2008, 4, e1000133. [CrossRef] [PubMed]

162. Grody, W.W. Molecular Genetic Risk Screening. Annu. Rev. Med. 2003, 54, 473-490. [CrossRef] [PubMed]

163. Sachidanandam, R.; Weissman, D.; Schmidt, S.C.; Kakol, J.M.; Stein, L.D.; Marth, G.; Sherry, S.; Mullikin, J.C.; Mortimore, B.J.; Willey, D.L.; et al. A map of human genome sequence variation containing 1.42 million single nucleotide polymorphisms. Nature 2010, 409, 928-933. [CrossRef] [PubMed]

164. Blau, N.; van Spronsen, F.J.; Levy, H.L. Phenylketonuria. Lancet (Lond., Engl.) 2010, 376, 1417-1427. [CrossRef]

165. Terry, P.; Lichtenstein, P.; Feychting, M.; Ahlbom, A.; Wolk, A. Fatty fish consumption and risk of prostate cancer. Lancet (Lond., Engl.) 2001, 357, 1764-1766. [CrossRef]

166. Morise, A.; Thomas, C.; Landrier, J.-F.; Besnard, P.; Hermier, D. Hepatic lipid metabolism response to dietary fatty acids is differently modulated by PPARalpha in male and female mice. Eur. J. Nutr. 2009, 48, 465-473. [CrossRef] [PubMed]

167. Dreja, T.; Jovanovic, Z.; Rasche, A.; Kluge, R.; Herwig, R.; Tung, Y.C.L.; Joost, H.G.; Yeo, G.S.H.; Al-Hasani, H. Diet-induced gene expression of isolated pancreatic islets from a polygenic mouse model of the metabolic syndrome. Diabetologia 2010, 53, 309-320. [CrossRef] [PubMed]

168. Ness, G.C.; Chambers, C.M. Feedback and hormonal regulation of hepatic 3-hydroxy-3-methylglutaryl coenzyme A reductase: The concept of cholesterol buffering capacity. Proc. Soc. Exp. Biol. Med. 2000, 224, 8-19. [CrossRef] [PubMed]

169. Cheema, S.K.; Clandinin, M.T. Dietary fat-induced suppression of lipogenic enzymes in B/B rats during the development of diabetes. Lipids 2000, 35, 421-425. [CrossRef] [PubMed]

170. Schmitz, G.; Ecker, J. The opposing effects of n-3 and n-6 fatty acids. Prog. Lipid Res. 2008, 47, 147-155. [CrossRef] [PubMed]

171. Chapkin, R.S.; Kim, W.; Lupton, J.R.; McMurray, D.N. Dietary docosahexaenoic and eicosapentaenoic acid: Emerging mediators of inflammation. Prostaglandins Leukot. Essent. Fat. Acids 2009, 81, 187-191. [CrossRef] [PubMed]

172. Bouwens, M.; van de Rest, O.; Dellschaft, N.; Bromhaar, M.G.; de Groot, L.C.; Geleijnse, J.M.; Müller, M.; Afman, L.A. Fish-oil supplementation induces antiinflammatory gene expression profiles in human blood mononuclear cells. Am. J. Clin. Nutr. 2009, 90, 415-424. [CrossRef] [PubMed]

173. Bünger, M.; Hooiveld, G.J.; Kersten, S.; Müller, M. Exploration of PPAR functions by microarray technologyA paradigm for nutrigenomics. Biochim. Biophys. Acta 2007, 1771, 1046-1064. [CrossRef] [PubMed] 
174. Cobb, J.P.; Mindrinos, M.N.; Miller-Graziano, C.; Calvano, S.E.; Baker, H.V.; Xiao, W.; Laudanski, K.; Brownstein, B.H.; Elson, C.M.; Hayden, D.L.; et al. Application of genome-wide expression analysis to human health and disease. Proc. Natl. Acad. Sci. USA 2005, 102, 4801-4806. [CrossRef] [PubMed]

175. Goyenechea, E.; Crujeiras, A.B.; Abete, I.; Martínez, J.A. Expression of two inflammation-related genes (RIPK3 and RNF216) in mononuclear cells is associated with weight-loss regain in obese subjects. J. Nutrigenet. Nutrigenom. 2009, 2, 78-84. [CrossRef] [PubMed]

176. Weisberg, S.P.; McCann, D.; Desai, M.; Rosenbaum, M.; Leibel, R.L.; Ferrante, A.W. Obesity is associated with macrophage accumulation in adipose tissue. J. Clin. Investig. 2003, 112, 1796-1808. [CrossRef] [PubMed]

177. Martin, K.J.; Graner, E.; Li, Y.; Price, L.M.; Kritzman, B.M.; Fournier, M.V.; Rhei, E.; Pardee, A.B. High-sensitivity array analysis of gene expression for the early detection of disseminated breast tumor cells in peripheral blood. Proc. Natl. Acad. Sci. USA 2001, 98, 2646-2651. [CrossRef] [PubMed]

178. Whitney, A.R.; Diehn, M.; Popper, S.J.; Alizadeh, A.A.; Boldrick, J.C.; Relman, D.A.; Brown, P.O. Individuality and variation in gene expression patterns in human blood. Proc. Natl. Acad. Sci. USA 2003, 100, 1896-1901. [CrossRef] [PubMed]

179. Quackenbush, J. Computational approaches to analysis of DNA microarray data. Yearb. Med. Inform. 2006, 1, 91-103.

180. Lee, W.-N.P.; Go, V.L.W. Nutrient-gene interaction: tracer-based metabolomics. J. Nutr. 2005, 135, 3027S-3032S. [PubMed]

181. Gibney, M.J.; Walsh, M.; Brennan, L.; Roche, H.M.; German, B.; van Ommen, B. Metabolomics in human nutrition: Opportunities and challenges. Am. J. Clin. Nutr. 2005, 82, 497-503. [PubMed]

182. Hollywood, K.; Brison, D.R.; Goodacre, R. Metabolomics: Current technologies and future trends. Proteomics 2006, 6, 4716-4723. [CrossRef] [PubMed]

183. Paolucci, U.; Vigneau-Callahan, K.E.; Shi, H.; Matson, W.R.; Kristal, B.S. Development of biomarkers based on diet-dependent metabolic serotypes: Characteristics of component-based models of metabolic serotypes. OMICS 2004, 8, 221-238. [CrossRef] [PubMed]

184. Lindon, J.C.; Holmes, E.; Nicholson, J.K. Metabonomics techniques and applications to pharmaceutical research \& amp; development. Pharm. Res. 2006, 23, 1075-1088. [PubMed]

185. Tsutsui, H.; Maeda, T.; Toyo'oka, T.; Min, J.Z.; Inagaki, S.; Higashi, T.; Kagawa, Y. Practical analytical approach for the identification of biomarker candidates in prediabetic state based upon metabonomic study by ultraperformance liquid chromatography coupled to electrospray ionization time-of-flight mass spectrometry. J. Proteome Res. 2010, 9, 3912-3922. [CrossRef] [PubMed]

186. Griffin, J.L. Understanding mouse models of disease through metabolomics. Curr. Opin. Chem. Biol. 2006, 10, 309-315. [CrossRef] [PubMed]

187. Gieger, C.; Geistlinger, L.; Altmaier, E.; Hrabé de Angelis, M.; Kronenberg, F.; Meitinger, T.; Mewes, H.-W.; Wichmann, H.-E.; Weinberger, K.M.; Adamski, J.; et al. Genetics meets metabolomics: A genome-wide association study of metabolite profiles in human serum. PLoS Genet. 2008, 4, e1000282. [CrossRef] [PubMed]

188. Kotronen, A.; Velagapudi, V.R.; Yetukuri, L.; Westerbacka, J.; Bergholm, R.; Ekroos, K.; Makkonen, J.; Taskinen, M.-R.; Oresic, M.; Yki-Järvinen, H. Serum saturated fatty acids containing triacylglycerols are better markers of insulin resistance than total serum triacylglycerol concentrations. Diabetologia 2009, 52, 684-690. [CrossRef] [PubMed]

189. Walsh, M.C.; Brennan, L.; Malthouse, J.P.G.; Roche, H.M.; Gibney, M.J. Effect of acute dietary standardization on the urinary, plasma, and salivary metabolomic profiles of healthy humans. Am. J. Clin. Nutr. 2006, 84, 531-539. [PubMed]

190. Mao, T.K.; van de Water, J.; Keen, C.L.; Schmitz, H.H.; Gershwin, M.E. Modulation of TNF-alpha secretion in peripheral blood mononuclear cells by cocoa flavanols and procyanidins. Dev. Immunol. 2002, 9, 135-141. [CrossRef] [PubMed]

191. Lenz, E.M.; Bright, J.; Wilson, I.D.; Hughes, A.; Morrisson, J.; Lindberg, H.; Lockton, A. Metabonomics, dietary influences and cultural differences: A 1H NMR-based study of urine samples obtained from healthy British and Swedish subjects. J. Pharm. Biomed. Anal. 2004, 36, 841-849. [CrossRef] [PubMed]

192. Lankinen, M.; Schwab, U.; Gopalacharyulu, P.V.; Seppänen-Laakso, T.; Yetukuri, L.; Sysi-Aho, M.; Kallio, P.; Suortti, T.; Laaksonen, D.E.; Gylling, H.; et al. Dietary carbohydrate modification alters serum metabolic profiles in individuals with the metabolic syndrome. Nutr. Metab. Cardiovasc. Dis. 2010, 20, $249-257$. [CrossRef] [PubMed] 
193. Lankinen, M.; Schwab, U.; Erkkilä, A.; Seppänen-Laakso, T.; Hannila, M.-L.; Mussalo, H.; Lehto, S.; Uusitupa, M.; Gylling, H.; Oresic, M. Fatty fish intake decreases lipids related to inflammation and insulin signaling-A lipidomics approach. PLoS ONE 2009, 4, e5258. [CrossRef] [PubMed]

194. Miccheli, A.; Marini, F.; Capuani, G.; Miccheli, A.T.; Delfini, M.; Di Cocco, M.E.; Puccetti, C.; Paci, M.; Rizzo, M.; Spataro, A. The influence of a sports drink on the postexercise metabolism of elite athletes as investigated by NMR-based metabolomics. J. Am. Coll. Nutr. 2009, 28, 553-564. [CrossRef] [PubMed]

195. De Hoog, C.L.; Mann, M. PROTEOMICS. Annu. Rev. Genom. Hum. Genet. 2004, 5, 267-293. [CrossRef] [PubMed]

196. Saleem, R.A.; Rogers, R.S.; Ratushny, A.V.; Dilworth, D.J.; Shannon, P.T.; Shteynberg, D.; Wan, Y.; Moritz, R.L.; Nesvizhskii, A.I.; Rachubinski, R.A.; et al. Integrated phosphoproteomics analysis of a signaling network governing nutrient response and peroxisome induction. Mol. Cell. Proteom. 2010, 9, 2076-2088. [CrossRef] [PubMed]

197. Pan, S.; Chen, R.; Crispin, D.A.; May, D.; Stevens, T.; McIntosh, M.W.; Bronner, M.P.; Ziogas, A.; Anton-Culver, H.; Brentnall, T.A. Protein alterations associated with pancreatic cancer and chronic pancreatitis found in human plasma using global quantitative proteomics profiling. J. Proteome Res. 2011, 10, 2359-2376. [CrossRef] [PubMed]

198. Canas, B.; López-Ferrer, D.; Ramos-Fernández, A.; Camafeita, E.; Calvo, E. Mass spectrometry technologies for proteomics. Brief. Funct. Genom. Proteom. 2006, 4, 295-320. [CrossRef] [PubMed]

199. Kussmann, M.; Krause, L.; Siffert, W. Nutrigenomics: Where are we with genetic and epigenetic markers for disposition and susceptibility? Nutr. Rev. 2010, 68, S38-S47. [CrossRef] [PubMed]

200. Kussmann, M.; Panchaud, A.; Affolter, M. Proteomics in nutrition: Status quo and outlook for biomarkers and bioactives. J. Proteome Res. 2010, 9, 4876-4887. [CrossRef] [PubMed]

201. Marvin-Guy, L.; Lopes, L.V.; Affolter, M.; Courtet-Compondu, M.-C.; Wagnière, S.; Bergonzelli, G.E.; Fay, L.B.; Kussmann, M. Proteomics of the rat gut: Analysis of the myenteric plexus-longitudinal muscle preparation. Proteomics 2005, 5, 2561-2569. [CrossRef] [PubMed]

202. Breikers, G.; van Breda, S.G.J.; Bouwman, F.G.; van Herwijnen, M.H.M.; Renes, J.; Mariman, E.C.M.; Kleinjans, J.C.S.; van Delft, J.H.M. Potential protein markers for nutritional health effects on colorectal cancer in the mouse as revealed by proteomics analysis. Proteomics 2006, 6, 2844-2852. [CrossRef] [PubMed]

203. Tan, S.; Seow, T.K.; Liang, R.C.; Koh, S.; Lee, C.P.C.; Chung, M.C.M.; Hooi, S.C. Proteome analysis of butyrate-treated human colon cancer cells (HT-29). Int. J. Cancer 2002, 98, 523-531. [CrossRef] [PubMed]

204. Herzog, A.; Kindermann, B.; Döring, F.; Daniel, H.; Wenzel, U. Pleiotropic molecular effects of the pro-apoptotic dietary constituent flavone in human colon cancer cells identified by protein and mRNA expression profiling. Proteomics 2004, 4, 2455-2464. [CrossRef] [PubMed]

205. Tom Dieck, H.; Döring, F.; Fuchs, D.; Roth, H.-P.; Daniel, H. Transcriptome and proteome analysis identifies the pathways that increase hepatic lipid accumulation in zinc-deficient rats. J. Nutr. 2005, 135, 199-205. [PubMed]

206. Zhang, L.; Perdomo, G.; Kim, D.H.; Qu, S.; Ringquist, S.; Trucco, M.; Dong, H.H. Proteomic analysis of fructose-induced fatty liver in hamsters. Metabolism 2008, 57, 1115-1124. [CrossRef] [PubMed]

207. Davis, C.D.; Milner, J. Frontiers in nutrigenomics, proteomics, metabolomics and cancer prevention. Mutat. Res. 2004, 551, 51-64. [CrossRef] [PubMed]

208. Ribarič, S. Diet and aging. Oxid. Med. Cell. Longev. 2012, 2012, 741468. [CrossRef] [PubMed]

209. Park, L.K.; Friso, S.; Choi, S.-W. Nutritional influences on epigenetics and age-related disease. Proc. Nutr. Soc. 2012, 71, 75-83. [CrossRef] [PubMed]

210. Marchesi, J.R.; Adams, D.H.; Fava, F.; Hermes, G.D.A.; Hirschfield, G.M.; Hold, G.; Quraishi, M.N.; Kinross, J.; Smidt, H.; Tuohy, K.M.; et al. The gut microbiota and host health: A new clinical frontier. Gut 2016, 65, 330-339. [CrossRef] [PubMed]

211. Panagiotou, G.; Nielsen, J. Nutritional systems biology: Definitions and approaches. Annu. Rev. Nutr. 2009, 29, 329-339. [CrossRef] [PubMed]

212. Kato, S.; Fujiki, R. Transcriptional controls by nuclear fat-soluble vitamin receptors through chromatin reorganization. Biosci. Biotechnol. Biochem. 2011, 75, 410-413. [CrossRef] [PubMed]

213. Knowles, L.M.; Milner, J.A. Diallyl disulfide induces ERK phosphorylation and alters gene expression profiles in human colon tumor cells. J. Nutr. 2003, 133, 2901-2906. [PubMed]

214. Kaput, J. Diet-disease gene interactions. Nutrition 2004, 20, 26-31. [CrossRef] [PubMed] 
215. Eletto, D.; Leone, A.; Bifulco, M.; Tecce, M.F. Effect of unsaturated fat intake from Mediterranean diet on rat liver mRNA expression profile: Selective modulation of genes involved in lipid metabolism. Nutr. Metab. Cardiovasc. Dis. 2005, 15, 13-23. [CrossRef] [PubMed]

216. Maere, S.; Heymans, K.; Kuiper, M. BiNGO: A Cytoscape plugin to assess overrepresentation of gene ontology categories in biological networks. Bioinformatics 2005, 21, 3448-3449. [CrossRef] [PubMed]

217. Shannon, P.; Markiel, A.; Ozier, O.; Baliga, N.S.; Wang, J.T.; Ramage, D.; Amin, N.; Schwikowski, B.; Ideker, T. Cytoscape: A software environment for integrated models of biomolecular interaction networks. Genome Res. 2003, 13, 2498-2504. [CrossRef] [PubMed]

218. Lehne, B.; Schlitt, T. Protein-protein interaction databases: Keeping up with growing interactomes. Hum. Genom. 2009, 3, 291-297.

219. Kuhn, M.; Szklarczyk, D.; Franceschini, A.; Campillos, M.; von Mering, C.; Jensen, L.J.; Beyer, A.; Bork, P. STITCH 2: An interaction network database for small molecules and proteins. Nucleic Acids Res. 2010, 38, D552-D556. [CrossRef] [PubMed]

220. Matthews, L.; Gopinath, G.; Gillespie, M.; Caudy, M.; Croft, D.; de Bono, B.; Garapati, P.; Hemish, J.; Hermjakob, H.; Jassal, B.; et al. Reactome knowledgebase of human biological pathways and processes. Nucleic Acids Res. 2009, 37, D619-D622. [CrossRef]

221. Caspi, R.; Altman, T.; Dale, J.M.; Dreher, K.; Fulcher, C.A.; Gilham, F.; Kaipa, P.; Karthikeyan, A.S.; Kothari, A.; Krummenacker, M.; et al. The MetaCyc database of metabolic pathways and enzymes and the BioCyc collection of pathway/genome databases. Nucleic Acids Res. 2010, 38, D473-D479. [CrossRef] [PubMed]

222. Finn, R.D.; Mistry, J.; Tate, J.; Coggill, P.; Heger, A.; Pollington, J.E.; Gavin, O.L.; Gunasekaran, P.; Ceric, G.; Forslund, K.; et al. The Pfam protein families database. Nucleic Acids Res. 2010, 38, D211-D222. [CrossRef] [PubMed]

223. Kouranov, A.; Xie, L.; de la Cruz, J.; Chen, L.; Westbrook, J.; Bourne, P.E.; Berman, H.M. The RCSB PDB information portal for structural genomics. Nucleic Acids Res. 2006, 34, D302-D305. [CrossRef] [PubMed]

224. Benson, D.A.; Karsch-Mizrachi, I.; Lipman, D.J.; Ostell, J.; Sayers, E.W. GenBank. Nucleic Acids Res. 2010, 38, D46-D51. [CrossRef] [PubMed]

225. Mendes, P.; Hoops, S.; Sahle, S.; Gauges, R.; Dada, J.; Kummer, U. Computational modeling of biochemical networks using COPASI. Methods Mol. Biol. 2009, 500, 17-59. [PubMed]

226. Funahashi, A.; Tanimura, N.; Matsuoka, Y.; Yosinaga, N.; Kitano, H. CellDesigner: A process diagram editor for gene-regulatory and biochemical networks. Biosilico 2003, 1, 169-176. [CrossRef]

227. Sauro, H.M.; Hucka, M.; Finney, A.; Wellock, C.; Bolouri, H.; Doyle, J.; Kitano, H. Next generation simulation tools: The Systems Biology Workbench and BioSPICE integration. OMICS 2003, 7, 355-372. [CrossRef] [PubMed]

228. Novère, N.L.; Hucka, M.; Mi, H.; Moodie, S.; Schreiber, F.; Sorokin, A.; Demir, E.; Wegner, K.; Aladjem, M.I.; Wimalaratne, S.M.; et al. The Systems Biology Graphical Notation. Nat. Biotechnol. 2009, 27, 735-741. [CrossRef] [PubMed]

229. Hucka, M.; Finney, A.; Bornstein, B.J.; Keating, S.M.; Shapiro, B.E.; Matthews, J.; Kovitz, B.L.; Schilstra, M.J.; Funahashi, A.; Doyle, J.C.; et al. Evolving a lingua franca and associated software infrastructure for computational systems biology: The Systems Biology Markup Language (SBML) project. Syst. Biol. (Stevenage) 2004, 1, 41-53. [CrossRef] [PubMed]

230. Desiere, F. Towards a systems biology understanding of human health: Interplay between genotype, environment and nutrition. Biotechnol. Annu. Rev. 2004, 10, 51-84. [PubMed]

231. Kitano, H. Systems biology: A brief overview. Science 2002, 295, 1662-1664. [CrossRef] [PubMed]

232. Ideker, T.; Galitski, T.; Hood, L. A new approach to decoding life: systems biology. Annu. Rev. Genom. Hum. Genet. 2001, 2, 343-372. [CrossRef] [PubMed]

233. Özdemir, V.; Kolker, E. Precision Nutrition 4.0: A Big Data and Ethics Foresight Analysis-Convergence of Agrigenomics, Nutrigenomics, Nutriproteomics, and Nutrimetabolomics. OMICS 2016, 20, 69-75. [CrossRef] [PubMed]

234. Ogino, S.; Stampfer, M. Lifestyle factors and microsatellite instability in colorectal cancer: the evolving field of molecular pathological epidemiology. J. Natl. Cancer Inst. 2010, 102, 365-367. [CrossRef] [PubMed]

235. Ogino, S.; Chan, A.T.; Fuchs, C.S.; Giovannucci, E. Molecular pathological epidemiology of colorectal neoplasia: An emerging transdisciplinary and interdisciplinary field. Gut 2011, 60, 397-411. [CrossRef] [PubMed] 
236. Hamada, T.; Keum, N.; Nishihara, R.; Ogino, S. Molecular pathological epidemiology: New developing frontiers of big data science to study etiologies and pathogenesis. J. Gastroenterol. 2016. [CrossRef] [PubMed]

237. Campbell, P.T.; Jacobs, E.T.; Ulrich, C.M.; Figueiredo, J.C.; Poynter, J.N.; McLaughlin, J.R.; Haile, R.W.; Jacobs, E.J.; Newcomb, P.A.; Potter, J.D.; et al. Case-control study of overweight, obesity, and colorectal cancer risk, overall and by tumor microsatellite instability status. J. Natl. Cancer Inst. 2010, 102, 391-400. [CrossRef] [PubMed]

238. Morikawa, T.; Kuchiba, A.; Yamauchi, M.; Meyerhardt, J.A.; Shima, K.; Nosho, K.; Chan, A.T.; Giovannucci, E.; Fuchs, C.S.; Ogino, S. Association of CTNNB1 (beta-catenin) alterations, body mass index, and physical activity with survival in patients with colorectal cancer. JAMA 2011, 305, 1685-1694. [CrossRef] [PubMed]

239. Morikawa, T.; Kuchiba, A.; Lochhead, P.; Nishihara, R.; Yamauchi, M.; Imamura, Y.; Liao, X.; Qian, Z.R.; $\mathrm{Ng}$, K.; Chan, A.T.; et al. Prospective analysis of body mass index, physical activity, and colorectal cancer risk associated with $\beta$-catenin (CTNNB1) status. Cancer Res. 2013, 73, 1600-1610. [CrossRef] [PubMed]

240. Morikawa, T.; Kuchiba, A.; Liao, X.; Imamura, Y.; Yamauchi, M.; Qian, Z.R.; Nishihara, R.; Sato, K.; Meyerhardt, J.A.; Fuchs, C.S.; et al. Tumor TP53 expression status, body mass index and prognosis in colorectal cancer. Int. J. Cancer 2012, 131, 1169-1178. [CrossRef] [PubMed]

241. Kuchiba, A.; Morikawa, T.; Yamauchi, M.; Imamura, Y.; Liao, X.; Chan, A.T.; Meyerhardt, J.A.; Giovannucci, E.; Fuchs, C.S.; Ogino, S. Body mass index and risk of colorectal cancer according to fatty acid synthase expression in the nurses' health study. J. Natl. Cancer Inst. 2012, 104, 415-420. [CrossRef]

242. Hanyuda, A.; Ogino, S.; Qian, Z.R.; Nishihara, R.; Song, M.; Mima, K.; Inamura, K.; Masugi, Y.; Wu, K.; Meyerhardt, J.A.; et al. Body mass index and risk of colorectal cancer according to tumor lymphocytic infiltrate. Int. J. Cancer 2016, 139, 854-868. [CrossRef] [PubMed]

243. Schernhammer, E.S.; Giovannucci, E.; Baba, Y.; Fuchs, C.S.; Ogino, S. B vitamins, methionine and alcohol intake and risk of colon cancer in relation to BRAF mutation and $\mathrm{CPG}$ island methylator phenotype (CIMP). PLoS ONE 2011, 6, e21102. [CrossRef] [PubMed]

244. Nishihara, R.; Wang, M.; Qian, Z.R.; Baba, Y.; Yamauchi, M.; Mima, K.; Sukawa, Y.; Kim, S.A.; Inamura, K.; Zhang, X.; et al. Alcohol, one-carbon nutrient intake, and risk of colorectal cancer according to tumor methylation level of IGF2 differentially methylated region. Am. J. Clin. Nutr. 2014, 100, 1479-1488. [CrossRef] [PubMed]

245. Dou, R.; Ng, K.; Giovannucci, E.L.; Manson, J.E.; Qian, Z.R.; Ogino, S. Vitamin D and colorectal cancer: molecular, epidemiological and clinical evidence. Br. J. Nutr. 2016, 115, 1643-1660. [CrossRef] [PubMed]

246. Zhang, X.; Keum, N.; Wu, K.; Smith-Warner, S.A.; Ogino, S.; Chan, A.T.; Fuchs, C.S.; Giovannucci, E.L. Calcium intake and colorectal cancer risk: Results from the nurses' health study and health professionals follow-up study. Int. J. Cancer 2016, 139, 2232-2242. [CrossRef] [PubMed]

247. Song, M.; Zhang, X.; Meyerhardt, J.A.; Giovannucci, E.L.; Ogino, S.; Fuchs, C.S.; Chan, A.T. Marine $\omega-3$ polyunsaturated fatty acid intake and survival after colorectal cancer diagnosis. Gut 2016. [CrossRef] [PubMed]

248. Mima, K.; Nishihara, R.; Yang, J.; Dou, R.; Masugi, Y.; Shi, Y.; da Silva, A.; Cao, Y.; Song, M.; Nowak, J.; et al. MicroRNA MIR21 (miR-21) and PTGS2 Expression in colorectal cancer and patient survival. Clin. Cancer Res. 2016, 22, 3841-3848. [CrossRef] [PubMed]

249. Dou, R.; Nishihara, R.; Cao, Y.; Hamada, T.; Mima, K.; Masuda, A.; Masugi, Y.; Shi, Y.; Gu, M.; Li, W.; et al. MicroRNA let-7, T Cells, and Patient Survival in Colorectal Cancer. Cancer Immunol. Res. 2016, 4, 927-935. [CrossRef] [PubMed]

250. Olivieri, F.; Spazzafumo, L.; Bonafè, M.; Recchioni, R.; Prattichizzo, F.; Marcheselli, F.; Micolucci, L.; Mensà, E.; Giuliani, A.; Santini, G.; et al. MiR-21-5p and miR-126a-3p levels in plasma and circulating angiogenic cells: relationship with type 2 diabetes complications. Oncotarget 2015, 6, 35372-35382. [PubMed]

251. Vrijens, K.; Bollati, V.; Nawrot, T.S. MicroRNAs as potential signatures of environmental exposure or effect: A systematic review. Environ. Health Perspect. 2015, 123, 399-411. [CrossRef] [PubMed]

252. Micolucci, L.; Akhtar, M.M.; Olivieri, F.; Rippo, M.R.; Procopio, A.D. Diagnostic value of microRNAs in asbestos exposure and malignant mesothelioma: Systematic review and qualitative meta-analysis. Oncotarget 2016, 7, 58606-58637. [CrossRef] [PubMed]

253. Bao, Y.; Prescott, J.; Yuan, C.; Zhang, M.; Kraft, P.; Babic, A.; Morales-Oyarvide, V.; Qian, Z.R.; Buring, J.E.; Cochrane, B.B.; et al. Leucocyte telomere length, genetic variants at the TERT gene region and risk of pancreatic cancer. Gut 2016. [CrossRef] [PubMed] 
254. Mima, K.; Nishihara, R.; Qian, Z.R.; Cao, Y.; Sukawa, Y.; Nowak, J.A.; Yang, J.; Dou, R.; Masugi, Y.; Song, M.; et al. Fusobacterium nucleatum in colorectal carcinoma tissue and patient prognosis. Gut 2015, 65, 1973-1980. [CrossRef] [PubMed]

255. Mima, K.; Cao, Y.; Chan, A.T.; Qian, Z.R.; Nowak, J.A.; Masugi, Y.; Shi, Y.; Song, M.; da Silva, A.; Gu, M.; et al. Fusobacterium nucleatum in Colorectal Carcinoma Tissue According to Tumor Location. Clin. Transl. Gastroenterol. 2016, 7, e200. [CrossRef] [PubMed]

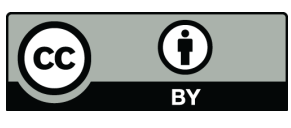

(C) 2017 by the authors; licensee MDPI, Basel, Switzerland. This article is an open access article distributed under the terms and conditions of the Creative Commons Attribution (CC-BY) license (http://creativecommons.org/licenses/by/4.0/). 